
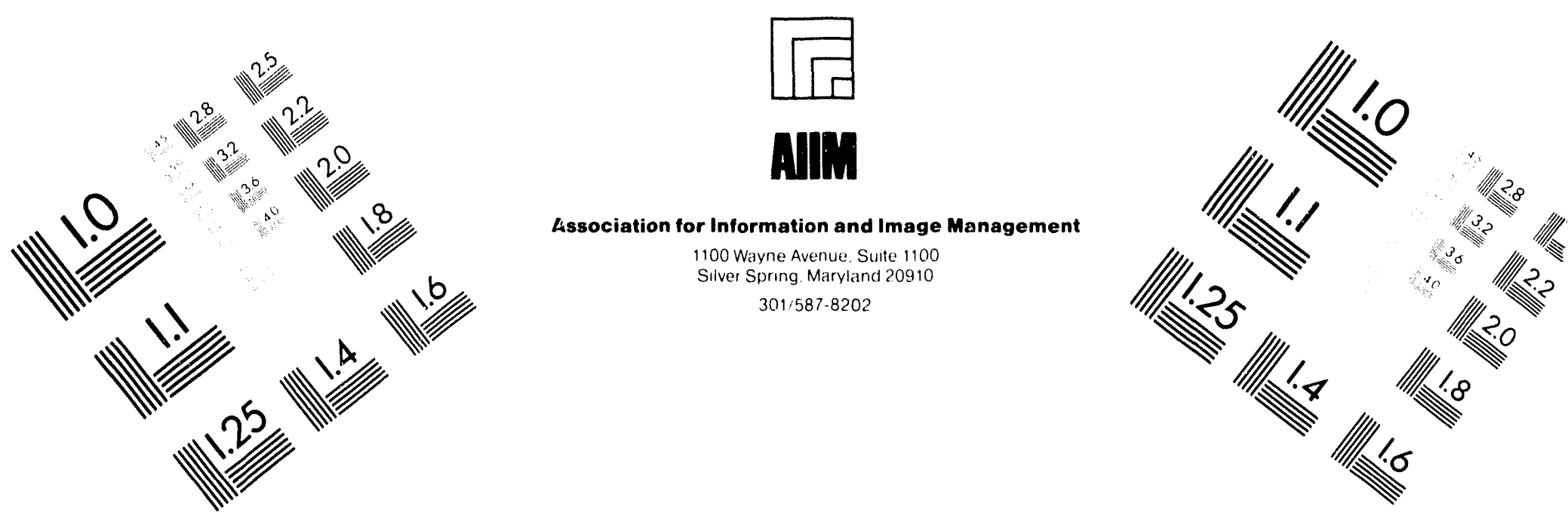

\title{
Centimeter
}

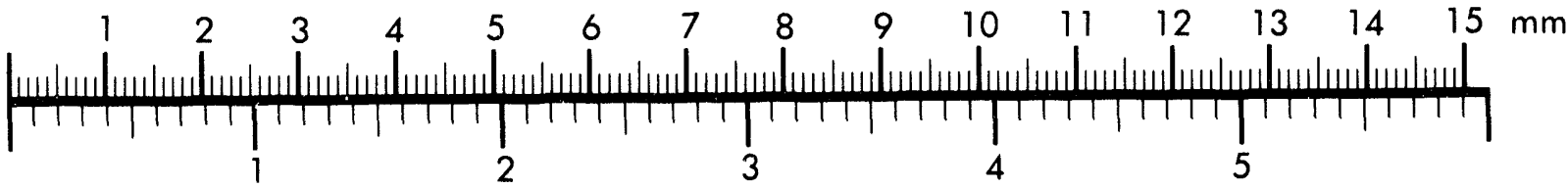

Inches
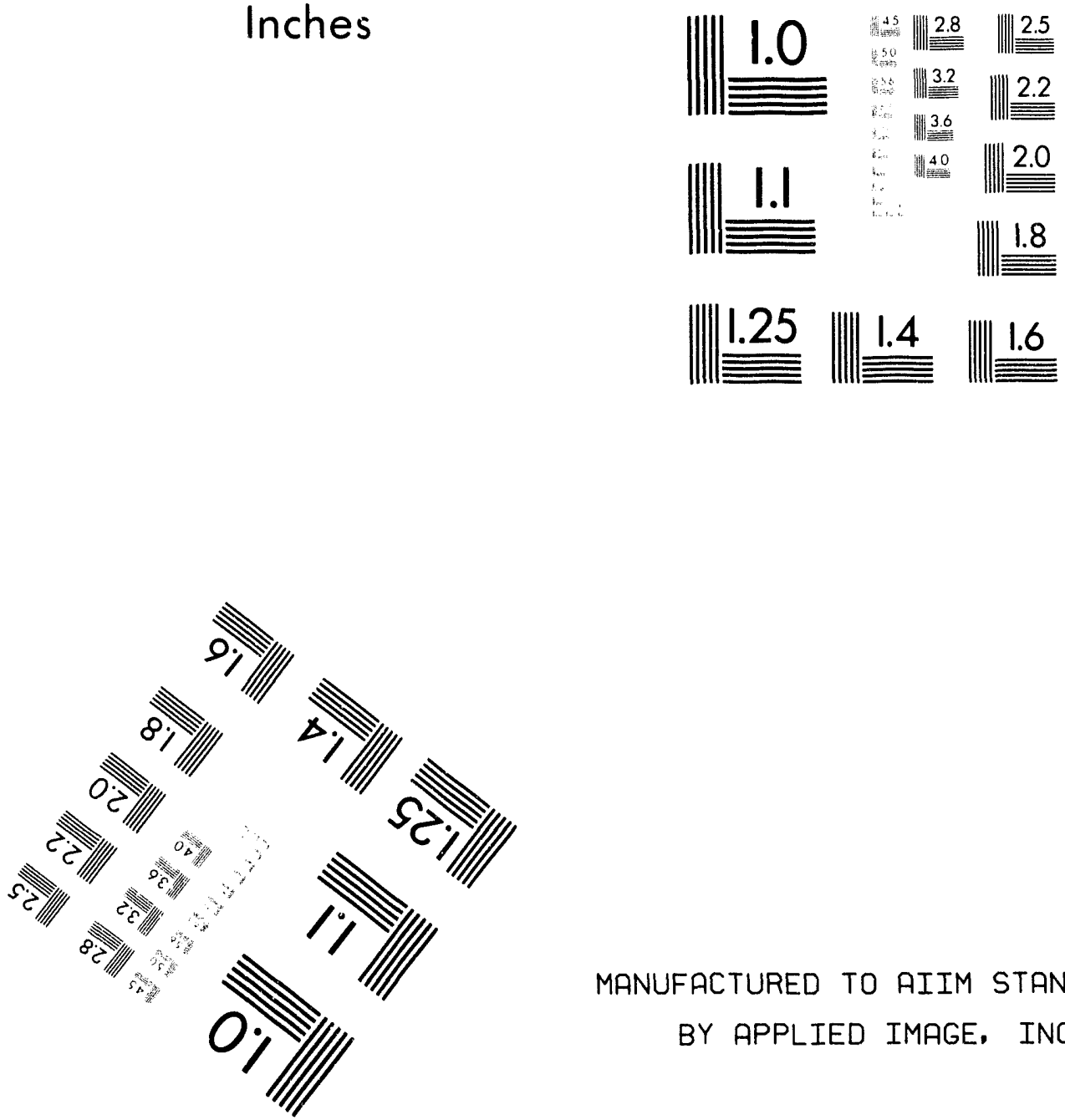

MANUFACTURED TO AIIM STANDARDS

BY APPLIED IMAGE, INC.

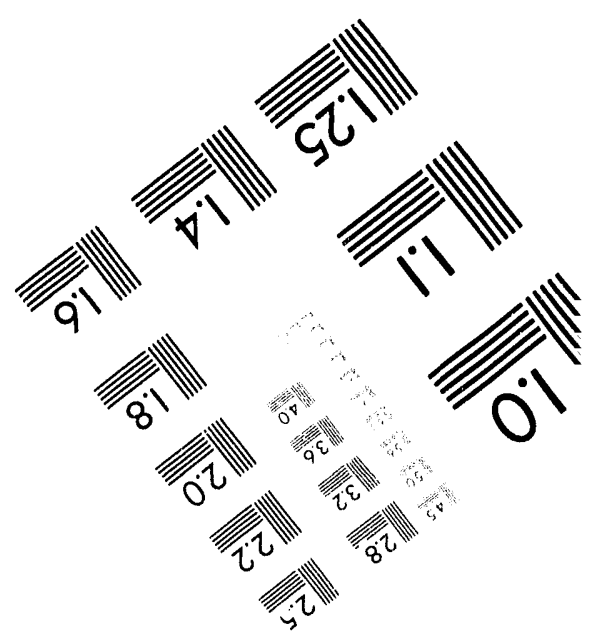




\section{Wildlife Studies on}

the Hanford Site:

1993 Highlights Report

L. L. Cadwell

April 1994

Prepared for the U.S. Department of Energy under Contract DE-AC06-76RLO 1830

Pacific Northwest Laboratory

Operated for the U.S. Department of Energy

by Battelle Memorial Institute

\% Battelle 


\title{
DISCLAIMER
}

This report was prepared as an account of work sponsored by an agency of the United States Government. Neither the United States Government nor any agency thereof, nor Battelle Memorial Institute, nor any of their employees, makes any warranty, expressed or implied, or assumes any legal liability or responsibility for the accuracy, completeness, or usefulness of any information, apparatus, product, or process disclosed, or represents that its use would not infringe privately owned rights. Reference herein to any specific commercial product, process, or service by trade name, trademark, manufacturer, or otherwise does not necessarily constitute or imply its endorsement, recommendation, or favoring by the United States Government or any agency thereof, or Battelle Memorial Institute. The views and opinions of authors expressed herein do not necessarily state or reflect those of the United States Government or any agency thereof.

\author{
PACIFIC NORTHWEST LABORATORY \\ operated by \\ BATTELLE MEMORIAL INSTITUTE \\ for the \\ UNITED STATES DEPARTMENT OF ENERGY \\ under Contract DE-ACO6-76RLO 1830
}

Printed in the United States of America

Available to DOE and DOE contractors frem the

Office of Scientific and Technical Information, P.O. Box 62, Oak Ridge, IN 37831; prices available from (615) 576-8401. FTS 626-8401.

Available to the public from the National Technical Information Service, U.S. Department of Commerce, 5285 Port Royal Rd., Springfield, VA 22161. 


\title{
Wildlife Studies on the Hanford Site: 1993 Highlights Report
}

\author{
L. L. Cadwell, Editor
}

April 1994

Prepared for the

U.S. Department of Energy

under Contract DE-AC06-76RLO 1830

Pacific Northwest Laboratory

Richland, Washington 99352

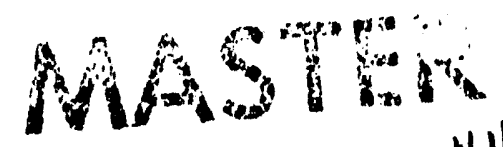




\section{Executive Summary}

Pacific Northwest Laboratory (PNL) manages the Hanford Site's Wildlife Resources Monitoring Project for the U.S. Department of Energy (DOE). The purposes of the project are to monitor and report trends in wildlife populations, conduct surveys to identify, record, and map populations of threatened, endangered, and sensitive plant and animal species, and cooperate with Washington State and federal and private agencies to help ensure the protection afforded by law to native species and their habitats.

Often, project staff work side by side with public and private agency staff, including the Washington Department of Wildlife (WDF), the U.S. Fish and Wildlife Service (USFWS), the Washington State Department of Natural Resources (DNR), the Washington State Department of Ecology (Ecology), and The Nature Conservancy (TNC) to collect data useful for protecting wildlife and plants and for landuse planning. Census data and results of surveys and special study topics are shared freely among cooperating agencies. Speciai studies are also conducted as needed to provide additional information that may be required to assess, protect, or manage wildlife resources at Hanford. This report describes highlights of wildlife studies on the Site in 1993 for both terrestrial and aquatic resources.

Redd counts of fall chinook salmon in the Hanford Reach suggest that the decline in salmon returning to spawn in the Columbia River adjacent to Hanford has continued each year since 1989 . The 1993 count (2873) declined by about $42 \%$ from 1992 and about $68 \%$ from the high in 1989 of approximately 9000 . Radiotelemetry data show that many Hanford Reach adult salmon migrate up the Snake River several miles before returning to the Columbia River.

Surveys conducted from 1988 through 1992 to determine the distribution of land and freshwater mollusks on the Hanford Site and surrounding areas show that five species of freshwater mollusks and six species of snails were found at 21 locations on the Site. Two fresh water species that are candidates for protection, were identified from samples of Columbia River benthos.

A habitat map, showing major vegetation and land use cover types for the Hanford Site was completed in 1993. The mapping effort was conducted in cooperation with WDW and Ecology. Wildlife Project staff also cooperated with TNC staff to initiate surveys for sage grouse, pygmy rabbits, and northern wormwood. Although no specimens of these species were found, maps detailing areas searched were created.

The 10 nesting pairs of ferruginous hawks that used the Hanford Site in 1993 represented approximately $25 \%$ of the Washington State population. Thus, it is apparent that Hanford land management decisions during environmental restoration have the potential to impact the future status of this species, currently listed as Washington State threatened.

The population of island-nesting Canada Geese in the Hanford Reach appears to be strong. In 1993, 196 of 235 pairs nested successfully. That compares with 213 of 286 nesting pairs in 1992. The trend in recent years has been a shift in use by nesting geese from upstream islands to those nearer Richland. Nest predation by coyotes appears to have restricted nesting on upstream islands more so than on downstream islands.

Data are provided on the results of bird surveys conducted in four distinct terrestrial habitat types at Hanford as well as the locations of great blue heron colonies along the Columbia River. Results from riparian habitat bird surveys in Snively Canyon also are included. These survey results will provide baseline data for evaluating change in relative abundance of bird species as environmental restoration progresses on the Hanford Site. Great blue herons have recently taken to nesting on transmission towers where a power line crosses the Columbia River. That adaptation by the birds suggests a scarcity of suitable groves along the shoreline, which are commonly used by these colonial nesters.

Mule deer studies have documented river crossings by deer marked in the 100 Areas. Some deer have moved to locations open to public hunting, including private property and the Wahluke Slope Wildlife Recreation Area. Analysis for ${ }^{90} \mathrm{Sr}$ in antler samples suggested that ${ }^{90} \mathrm{Sr}$ content was somewhat greater in 100-Area deer than in deer from the Hanfora townsite and south; however, a limited number of samples from shed antlers does not confirm that result. The occurrence of abnormal antler development and atrophied testicles in some male deer is discussed, as are preliminary study results and plans for continuing to investigate possible causes for the abnormalities. 
Elk count data through 1992 indicate a maximum of approximately 190 head. Estimates for 1993 will not be completed until early 1994 . A study to evaluate birth control techniques and to determine the extent of associated behavioral response in Rocky Mountain elk is described.

The wildlife resources database is also described. Recent efforts have included entering large amounts of historical data into a computerized system and timely entry of current information as it is being collected. Data displays that include capabilities to create Geographical Information System (GIS) map layers are also being added to the system. We envision that as the Wildlife Resources Database continues to grow, so will its value both to DOE Site managers and planners, and to interested stakeholders planning for future development and uses of the Hanford Site. 


\section{Contents}

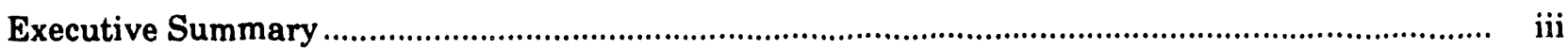

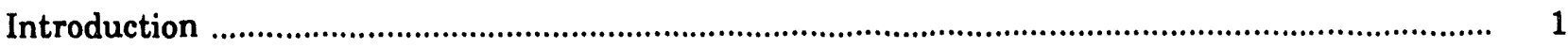

Wildlife Monitoring Project Studies ............................................................................................

Salmon Survey D.D. Dauble and D.R. Geist ....................................................................... 3

Malacofauna of the Hanford Site D.A. Neitzel ....................................................................... 4

Habitat on Hanford J.L. Downs, J.J. Nugent and L.L. Cadwell .............................................. 5

Wildlife and Plant Species of Concern J.L. Downs and R. Mazaika ....................................... 7

Bald Eagles, Nesting Canada Geese, and Hawks R. Mazaika .................................................. 9

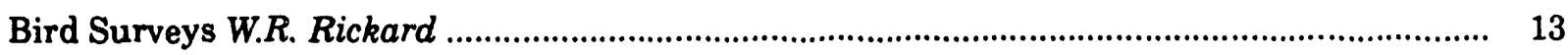

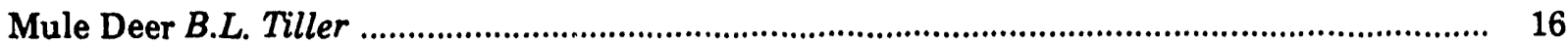

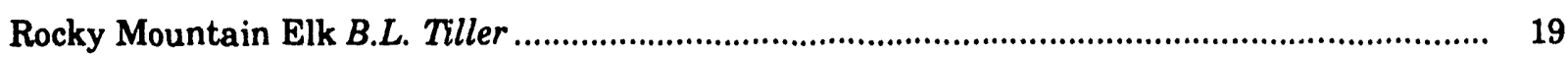

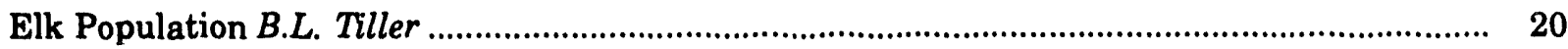

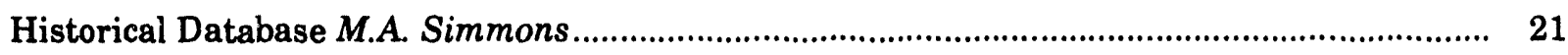

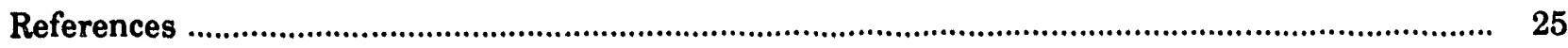

Appendix A -Endangered, Threatened, and Candidate Species of the Hanford Site ................... A.1 


\section{Figures}

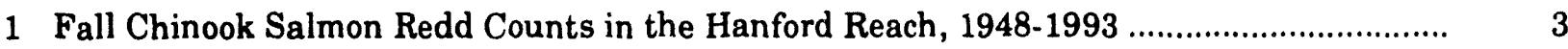

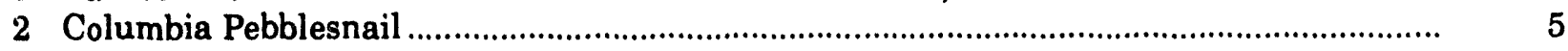

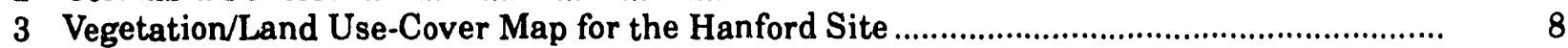

4 Pygmy Rabbit Search Areas on Hanford Site, 1992-1993 ................................................. 10

5 Northern Wormwood Search Areas on the Hanford Site, 1993 ......................................... . 11

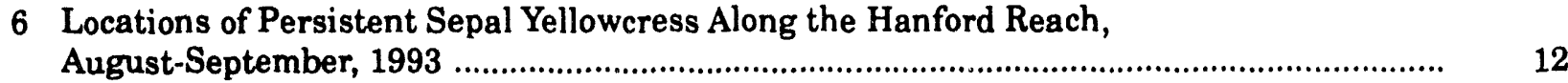

7 Bald Eagle Counts in the Hanford Reach, 1961-1992 .........................................................

8 Survey Routes "A," "B," "C," and " $D$ " for Breeding Birds on the Hanford Site ....................... 14

9 Hanford Deer Locations Relative to Capture Sites, 1991-1992 ........................................... 18

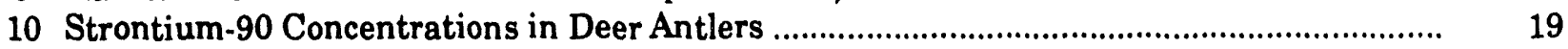

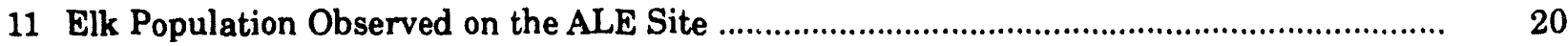

\section{Tables}

1 Species of Special Concern in Washington-State and Federal Status

2 Status of Persistent Sepal Yellowcress, Pygmy Rabbit, Sage Grouse, and Northern Wormwood

3 Numbers of Shrub-Steppe Birds Recorded Along Four Survey Routes "A," "B," "C," and "D", May 1993

4 Age and Sex Classification of Elk Herd on the Fitzner/Eberhardt ALE Reserve

5 Data Sets to Be Included in a Hanford Site Wildlife Database. 


\section{Introduction}

Wildlife living on the Hanford Site, as is true for public and private property elsewhere in Washington, do not belong to the U.S. Department of Energy (DOE). Rather, they belong to the state, and the Washington Department of Wildlife (WDW) has the primary responsibility for their management. Some migratory wildlife species that cross state boundaries also fall under the jurisdiction of the U.S. Fish and Wildlife Service (USFWS). The USFWS monitors and coordinates the protection of both plant and animal species that have been identified as threatened or endangered on the federal level as mandated by the Endangered Species Act (ESA). Animal species similarly identified on the state level are protected by WDW. Plants that have been identified in the state as threatened or endangered are monitored and protected by the Washington State Department of Natural Resources (DNR).

The Pacific Northwest Laboratory (PNL) Wildlife Resources Monitoring Project was initiated by DOE to track the status of wildlife populations to determine whether Hanford operations affected them. The project continues to conduct a census of wildlife populations that are highly visible, economically or aesthetically important, and rare or otherwise considered sensitive. Examples of long-term data collected and maintained through the Wildlife Resources Monitoring Project include annual goose nesting surveys conducted on islands in the Hanford Reach, wintering bald eagle surveys, and fall Chinook salmon redd (nest) surveys.

Identifying and mapping habitats on the Hanford Site for threatened, endangered, and otherwise sensitive species has, in recent years, become an increasingly important function of the Wildlife Project. Our staff coordinates with both researchers and enforcement personnel at state and federal levels to help ensure the identification and protection of plants and animals as directed by Washingtrn State codes and federal regulations.

Often, project staff work side by side with public and private agency staff, including the Washington Department of Wildlife (WDF), the U.S. Fish and Wildlife Service (USFWS), the Washington State Department of Natural Resources (DNR), the Washington State Department of Ecology (Ecology), and The Nature Conservancy (TNC) to collect data useful for protecting wildlife and plants and for landuse planning. Census data and results of surveys and special study topics are shared freely among cooperating agencies.

This first annual report summarizes various activities conducted by the Wildlife Resources Monitoring Project. Although the report emphasizes the 1993 calendar year, data results from previous years also have been included to show trends, where appropriate.

The report highlights activities related to salmon and mollusks on the Hanford Reach of the Columbia River; describes efforts to map vegetation on the Site and efforts to survey species of concern; provides descriptions of shrub-steppe bird surveys, including bald eagles, Canada geese, and hawks; outlines efforts to monitor mule deer and elk populations on the Site; and describes development of a biological database management system (Ecological Data Manager). 


\section{Wildlife Monitoring Project Studies}

\section{Salmon Survey D.D. Dauble and D.R. Geist}

The objective of the salmon survey task is to survey spawning sites of fall chinook salmon (Oncorhynchus tshawytscha) in the Hanford Reach of the Columbia River. These surveys are typically conducted at weekly intervals from mid-October through late November. Data collected include time of initial spawning activity, peak spawning interval, and total redds observed in designated index sites. Other activities include radiotracking of adult fall chinook salmon, identifying critical habitat, and reporting the information to fisheries management agencies.

\section{Aerial Surveys}

During 1993, we conducted five aerial surveys of fall chinook salmon spawning areas in the Hanford Reach. The surveys were conducted weekly from late October through the end of November and covered the peak spawning interval. The peak redd counts for fall chinook salmon in the Hanford Reach was estimated at 2873. The 1993 total was the lowest in more than a decade and comparable to those noted in the late 1970s (Figure 1). The estimate was consistent with expected escapement based on counts of adult salmon passing McNary Dam.

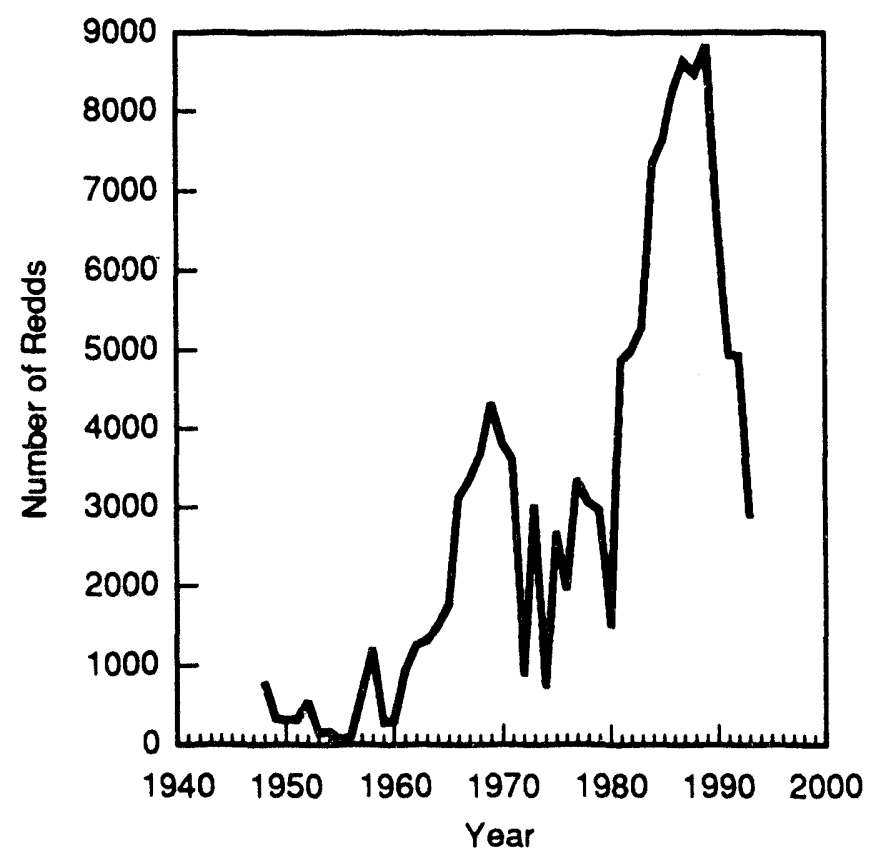

Figure 1. Fall Chinook Salmon Redd Counts in the Hanford Reach, 1948-1993
The low flow regime established at Priest Rapids Dam helped in locating redds in the upper part of the reach during both years. However, water levels near the 100-F slough and at Ringold were still high during the mid-day surveys (i.e., flows appeared above average discharge or $>120 \mathrm{Kcfs}$ ), and low redd counts in these areas may have been partially a result of depth of water over the redds.

\section{Radiotelemetry Studies}

In fall 1993, the Washington Department of Fisheries (WDF) radiotagged and released 200 adult fall chinook salmon in the lower Snake River. The WDF did not monitor the movement patterns of salmon in the Hanford Reach because their study objective was to determine passage problems in the Snake River. With the assistance of a student in the Science and Engineering Research Semester (SERS) program, we used these WDF-tagged fish to collect information on pre-spawning habitat use of adult salmon in the Hanford Reach.

Radiotagged fish were monitored at least 3 days per week from early October through the end of December 1993. Twenty-nine surveys were completed using truck, boat, and aircraft. Preliminary results indicate that approximately $25 \%$ of the fish tagged in the lower Snake River were located at least once in the Hanford Reach. Some fish traveled more than $250 \mathrm{~km}$ from the tagging location and entered and exited the Hanford Reach several times. Fish were observed to move from 1 to $30 \mathrm{~km}$ per day when actively migrating, and held up to 21 days in one location before spawning, generally downstream of the spawning areas. Final analysis and summary of radiotelemetry data will be completed in 1994 .

\section{Characterization of Spawning Habitat}

We also continued to develop a conceptual model of critical habitat for fall chincok salmon using students funded through the former-Northwest College and University Association for Science (NORCUS) and SERS programs. Current hydrologic-based models appear to overestimate available spawning habitat and could lead to unrealistic expectations of the recovery potential of certain stocks, including those listed as threatened and endangered under the Endangered Species Act (ESA). Thus, we evaluated spawning habitat of fall chinook salmon in the Hanford Reach of the Columbia River to determine 
if increased escapement might lead to use of currently unused spawning habitat. General land form and channel morphometry features were described, and their dimensions were related to redd densities obtained by aerial surveys. Channel cross sections were used to predict mean velocity and stream discharge.

Our results showed that distinct velocity gradients occurred where the river changed from a single channel to a braided channel. Differences in measurement dimensions made it difficult to define a relationship between velocity gradients and preferred spawning habitat. However, higher redd densities were located where the river channel widened and where changes in flow volumes indicated increased substrate permeability. We are currently attempting to integrate field data with modeling efforts to account for differences in spatial scale. This approach may be applicable to evaluating the potential for recovery of other salmon populations, including Snake River stocks listed under the ESA in 1992.

A presentation was made to the annual meeting of the American Fisheries Society in Portland, Oregon, September 2, 1993, titled "Geomorphological Approach to Characterizing Fall Chinook Salmon Spawning Habitat in the Mainstem Columbia River," by D.D Dauble and G. Hamisfar.

\section{Future Plans}

In CY 1994 we will improve on the definition of critical habitat of adult fall chinook salmon in the Hanford Reach. We will continue to conduct the aerial redd surveys and will use radiotelemetry data to determine the behavior and habitat selection of pre-spawning adult salmon. Information on adult holding areas and spawning sites will be entered into the project data base and will be available for analysis using Geographic Information System (GIS) techniques.

We are also exploring the possibility of accessing a Long Baseline Radiotracking System (LBRTS). The LBRTS allows us to collect much more data on the movement of adult fish (or other animals) with a far greater accuracy than present technology.

\section{Malacofauna of the Hanford Site D. A. Neitzel}

Assessing the beneficial uses of the Columbia River and surrounding land at Hanford is enhanced by knowing the distribution of plants and animals that live there. Surveys were conducted from 1988 through 1992 to determine the distribution of land and freshwater mollusks on the Hanford Site and surrounding areas.

Five species of freshwater mollusks and six species of land snails were found at 21 localities on recent surveys of the Site. Two fresh water species that are candidates for protection were identified from samples of Columbia River benthos.

The malacofauna of the Site is sparse compared with that of other areas in Washington with roughly comcarable substrate and climate. Most species found at Hanford are widely distributed forms or are introduced (non-native) taxa. Not a single endemic land snail (Cryptomastix $n$. sp.) has been found at a single location on the Site. This species likely will be considered a candidate for federal listing. Geologic factors and human modification of spring habitats (e.g., pipe installation in some of the springs) are the likely causes for the depauperate mollusks.

Previous surveys focused specifically on two species of freshwater mollusks that nccur at Hanford-the Columbia pebble snail (Fluminicola columbiana) (Figure 2) and shortface lanx (Fisherola nuttalli) because of their interest as candidates for protection. Currently, only two remaining sizable populations of Columbia pebblesnail exist: those in the Methow and Okanogan rivers, Washington. Smaller populations survive in the Hanford Reach of the Columbia River, Washington; the lower Salmon and middle Snake rivers, Idaho; and possibly Hells Canyon of the Snake River, Idaho, Washington, and Oregon; and The Grande Ronde River, Oregon and Washington. Neither large population is currently protected, and a substantial reduction has been noted in the species' historical range.

Large populations of the shortface lanx persist in four streams: The Deschutes River, Oregon; the Hanford Reach of the Columbia River, Washington; Hells Canyon of the Snake River, Idaho and Oregon; and the Okanogan River, Washington. Smaller populations, or ones of uncertain size, are known from the lower Salmon and middle Snake rivers, Idaho, The Grande Ronde River, Washington and Oregon; and the Methow River, Washington. Though the range of this species has been substantially reduced, and the large populations are not well protected, the problem is not as severe as it is with the Columbia pebblesnail. 


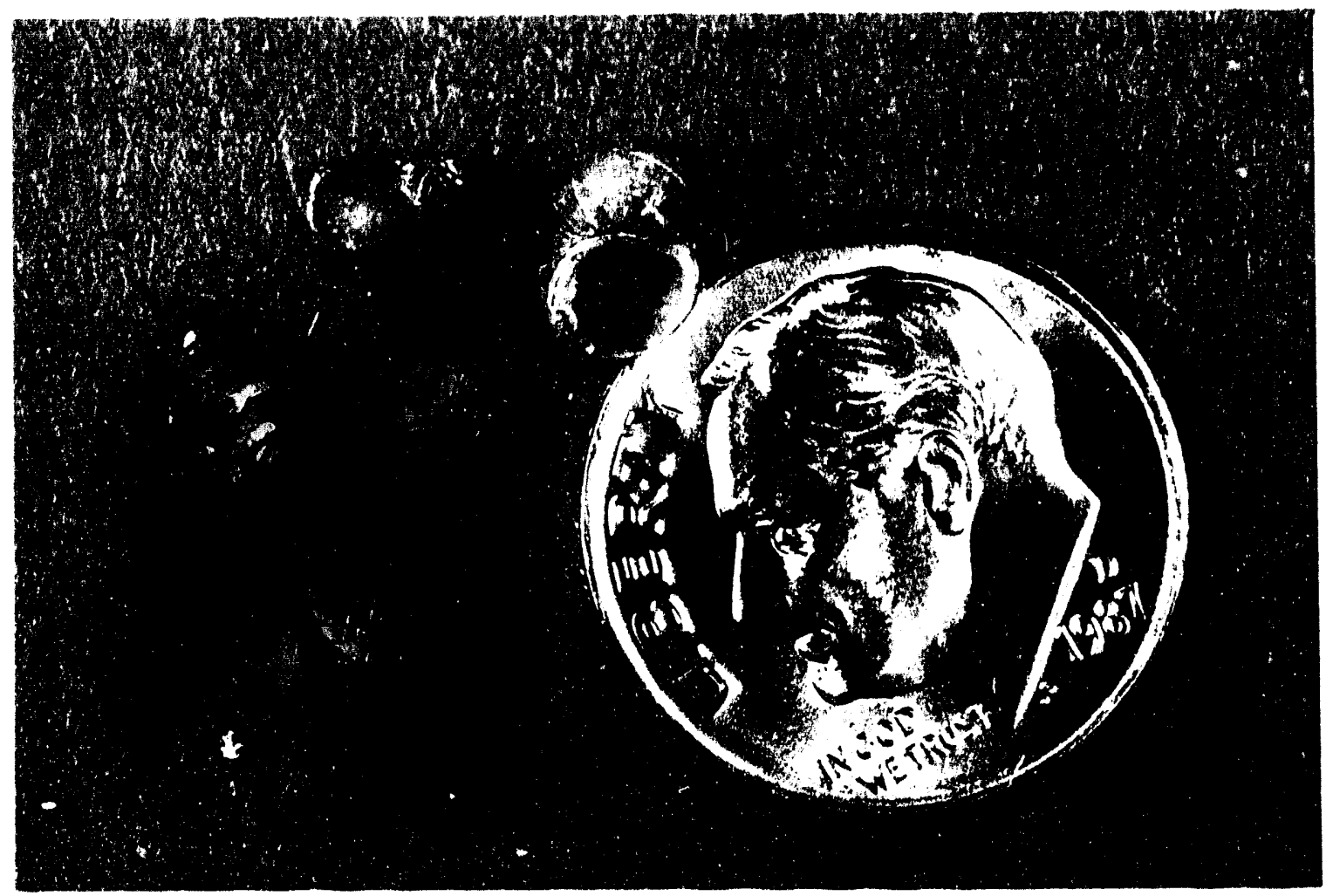

Figure 2. Columbia Pebblesnail

\section{Habitat on Hanford}

\section{J.L. Downs, J.J. Nugent and L.L. Cadwell}

The Hanford Site supports one of the last remaining contiguous large tracts of shrub-steppe habitat within Washington State. As part of the Wildlife Resources Monitoring Project, efforts were made during 1993 to develop a detailed map of vegetation associations on the Site. Maps delineating the extent of existing big sagebrush (Artemisia tridentata) habitat and other native vegetation associations will aid in research and management for particular wildlife species of concern and in identifying sensitive and critical habitat areas on the Site.

The amount of sagebrush habitat in Washington has been drastically reduced over the last 100 years through urban and agricultural development. These reductions in available habitat across the eastern portion of the state pose a serious threat to the wellbeing of wildlife populations that require sagebrush habitat. Vegetation associations that include big sagebrush as a dominant shrub are critical to a number of wildlife species, including sage grouse (Centrocercus urophasianus), loggerhead shrikes (Lanius ludovicianus), sage sparrows (Amphispiza belli), and sage thrashers (Oreoscoptes montanus). Black-tailed jackrabbits (Lepus californicus), and other small mammals that depend on sagebrush for food and cover provide an important food source for predators higher on the food chain such as the ferruginous hawk. Several of these species, including the sage sparrow, sage thrasher, loggerhead shrike, and pygmy rabbit (Brachylagus idahoensis) are either candidates for state listing or are already listed as sensitive, threatened, or endangered within the state. Table 1 defines state and federal status of special species of concern.

To provide information concerning available and potential habitat areas for species of concern, maps of vegetation associations across the entire Hanford Site were traced from medium-altitude, color aerial photography flown in 1987 (1:20000) and 1991 (1:24000). Only the center one-third of overlapping photographs was used to minimize the amount of relief displacement. Color enlargements were used to aid in identifying ground cover. The 1991 photography was provided by Benton County for that portion of the Hanford Site lying within county boundaries. The areas outside of Benton County, which for the most part include the portion of the Site north and east of the Columbia River, were drawn from 1987 aerial photography originally flown for the Basalt Waste Isolation Program. 
Table 1. Species of Special Concern in Washington-State and Federal Status ${ }^{(\mathbf{a})}$

Federal Status Definitions

Federal Endangered-A species in danger of extinction throughout all or a significant portion of its range. Federal Threatened-A species likely to become endangered within the foreseeable future.

Federal Proposed-A species that is the subject of a proposed or final rule indicating the appropriateness of listing as threatened or endangered.

Federal Candidate Category 1-A species that is a candidate for listing under the Endangered Species Act. U.S. Fish and Wildlife Service has substantial evidence to support listing as a threatened or endangered species.

Federal Candidate Category 2-A species that is a candidate for listing under the Endangered Species Act. Listing is possibly appropriate but conclusive information is lacking.

Federal Candidace Cetegory 3-A species that was once considered for listing under the Endangered Species Act that is no longer being considered.

\section{State Status Definitions}

State Endangered-Wildlife species native to the state of Washington seriously threatened with extinction throughout all or a significant part of their ranges within the state. Endangered species are legally designated in WAC 232-12-014.

State Threatened - V ildlife species native to the state of Washington likely tn become endangered within the foreseeable future throughout significant portions of their ranges within the state without cooperative management or the removal of threats. Threatened species are legally designated in WAC 232-12-011.

State Sensitive-Wildlife species native to the state of Washington that are vulnerable or declining and are likely to become endangered or threatened in a significant portion of their ranges within the state without cooperative management or the removal of threats. Sensitive species are legally designated in WAC 232-12-011.

State Candidate-Wildlife species that are under review by WDW for possible listing as endangered, threatened, or sensitive. A species will be considered for State Candidate designation if sufficient evidence suggests that its status may meet criteria defined for endangered, threatened, or sensitive in WAC 232-12297. Currently listed State Threatened or State Sensitive species may also be designated as a State Candidate species if their status is in question. State Candidate Species will be managed by the Department, as needed, to ensure the long-term survival of populations in Washington. They are listed in WDW Policy 4802.

State Monitor-Wildlife species native to the state of Washington that:

1) were at one time classified as endangered, threatened, or sensitive

2) require habitat that has limited availability during some portion of its life cycle

3) are indicators of environmental quality

4) require further field investigations to determine population status

5) have unresolved taxonomy that may bear upon their status classification

6) may be competing with and impacting other species of concern

7) have significant popular appeal.

State Monitor species will be managed by WDW, as needed, to prevent them from becoming endangered, threatened, or sensitive.

Species already classified in a category that provides adequate management emphasis, survey work, and data maintenance (e.g., game animals, game birds, furbearers, etc.) will not be designated as State Monitor species. Monitor species are designated in WDW Policy 4803.

(a) Source: Washington Department of Wildlife. 
Original tracings were overlain and registered on U.S. Geographical Survey (USGS) 7.5-minute topographic maps, and the data were digitized for use in a GIS. Locations were referenced to existing roadways identified on both the aerial photographs and topographic maps. Classifications of land use/ vegetation were verified through field observations in as many areas as possible. Areas that are remote and not accessible from existing roadways were not visited and so are assumed to be represented by the designated cover class. However, further verification may be required for site-specific uses.

Vegetation data were collected on site in spring and summer 1993 through a cooperative effort with WDW and Ecology. This information may be used both to further refine vegetation cover classifications onsite and to verify the classifications.

The current map of vegetation/land use cover for the Hanford Site includes 13 classifications (Figure 3). The map layer resides in the Geographical Resources Analysis Support System (GRASS) format on the GIS and can be used in conjunction with the biological database system (Ecological Data Manager), which is described in the last section of this report.

Future work will be directed to refine the vegetation classifications and continue to verify the map. Development and further refinement of this map layer will be especially helpful to ongoing wildlife monitoring efforts and in evaluating habitat on the site with regard to cleanup activities. Because vegetation on the Site will continue to change in response to natural and human-caused events, this map should be considered a "living document" that will continue to be updated to reflect changes in cover type and to include verification data. All potential users of the vegetation/land-use cover map for the Hanford Site are advised to contact the Wildlife Resources Monitoring Project to acquire the most recent version.

\section{Wildlife and Plant Species of Concern J.L. Downs and R. Mazaika}

During the last year, the Wildlife Resources Monituring Project began efforts to survey for several species of concern (Table 2) on the Hanford Site, including the western subspecies of sage grouse, pygmy rabbit, and northern wormwood (Artemisia campestris subsp. borealis var. wormskioldii).

Communications with WDW, DNR, and TNC identified these three species from the several species listed at either the federal or state level (Appendix A) as species for which impcrtant information was lacking concerning their status on the Hanford Site. Surveys were also conducted along the Columbia River for persistent sepal yellowcress (Rorippa columbiae) during summer and fall.

The two wildlife species, sage grouse and pygmy rabbit, were previously reported as residents of the Fitzner Eberhardt Arid Lands Ecology (ALE) Reserve, but no sightings of either species have been reported in the last several years. Both pygmy rabbits and sage grouse prefer sagebrush habitat. Wildfires removed much of the sagebrush from ALE in the $1980 \mathrm{~s}$, and little information has been gathered as to the current status of the pygmy rabbit and sage grouse. Northern worm wood, a low-growing herbaceous plant, has not been found on the Hanford Site, but a population is known to be located north of the Hanford Site along the Columbia River. Surveys to locate previously known populations of $R$. columbiae and to search for new populations were conducted in August and September. These sites will be used to evaluate the effects of hydraulic management on the health and status of the species.

\section{Sage Grouse Surveys}

Under a Memorandum of Understanding (MOU) between DOE and TNC, PNL staff cooperated with TNC staff and WDW in surveying many of the remaining sagebrush stands on the Hanford Site for sage grouse. Surveys were conducted in late winter/ early spring 1993.

Areas surveyed included sagebrush habitat on slopes across the Hanford Site and historical lek locations recorded by WDW. (Lek describes the area where sage grouse traditionally return to participate in courtship display.) Because the birds return to leks in groups to display in early morning, surveys were conducted during predawn and sunrise hours at known lek sites. These surveys were believed to be one of the best methods to detect sage grouse activity. Pedestrian surveys of likely sagebrush habitat areas were conducted by walking transects through remaining sagebrush habitat and visually searching for signs of sage grouse such as droppings or roosting sites.

No sage grouse were sighted during the 1993 surveys of lek sites or the pedestrian survey of likely habitat areas. Inclement weather (i.e., fog and snowfall) during February and March affected the timing and completion of the surveys and may have contributed to a lack of success in finding sage grouse. In addition, although much of the likely sagebrush habitat was investigated, many areas on ALE are relatively remote and not easily accessed. 
(November 1, 1993, Rev. 0)*

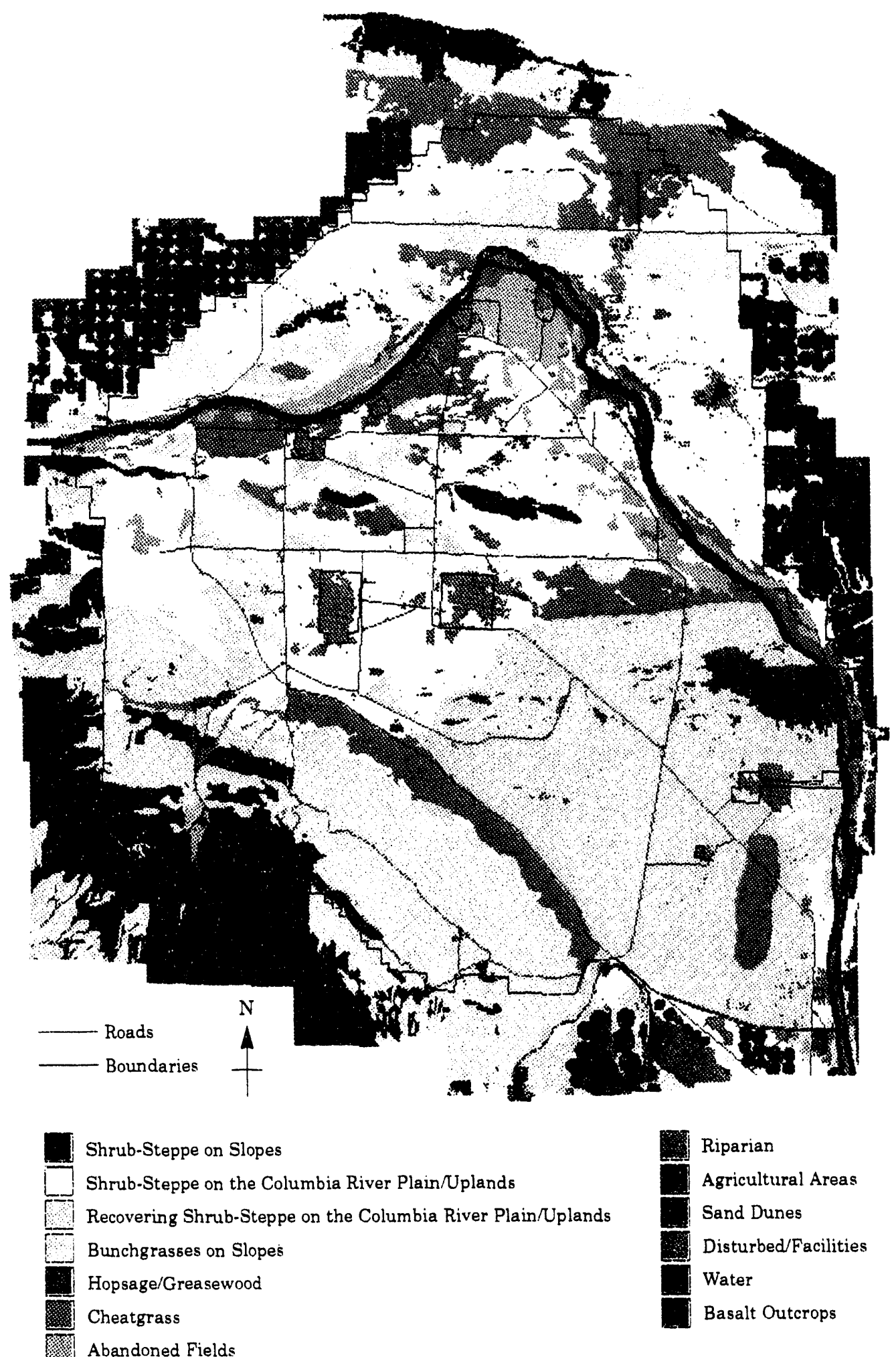

*Based on 1997 and 1991 aerial photography.

Map subject to revision as additional survey data become avallable and as

cover types change in res ponse to natural and human-caused events

Figure 3. Vegetation/Land-Use Cover Map for the Hanford Site 
Table 2. Status of Persistent Sepal Yellowcress, Pygmy Rabbit, Sage Grouse, and Northern Wormwood (see Table 1 for definitions of state and federal status)

Common Name

Persistent sepal yellowcress

Pygmy rabbit

Sage grouse

Northern

wormwood

\begin{tabular}{l} 
Latin Name \\
\hline Rorippa columbiae \\
Brachylagus idahoensis \\
Centrocercus \\
urophasianus phaios
\end{tabular}

Artemisia campestris var. wormskioldii

\begin{tabular}{|c|c|}
\hline Federal Status & State Status \\
\hline Candidate 2 & Endangered \\
\hline Candidate 2 & Endangered \\
\hline Candidate 2 & Candidate \\
\hline Candidate 1 & Endanger \\
\hline
\end{tabular}

\section{Pygmy Rabbit Surveys}

Areas of the Hanford Site where dense sagebrush stands occur were surveyed for indications of pygmy rabbits in fall, winter, and spring 1993 (Figure 4). Pygmy rabbits prefer habitat that includes dense shrub cover and deep, friable soils in which they can dig burrows. Pygmy rabbits are the only rabbit in North America that digs its own burrows and are also the smallest rabbit in North America. In Washington State, populations are only known to occur in five isolated fragments of suitable habitat, all in Douglas County north of the Hanford Site (WDW 1993). Areas on the site were surveyed by walking transects through the areas searching for evidence of burrows along gentle slopes. The ground surface in these areas was also visually searched for pellets (feces) exhibiting the size and shape characteristic of pygmy rabbits. Our survey efforts did not locate evidence of pygmy rabbit populations in the dense sagebrush habitat areas surveyed (Figure 4).

\section{Northem Wormwood Surveys}

Northern wormwood has not been found on the Hanford Site, but one of the two known populations for this species occurs upstream within $25 \mathrm{~km}$ of Site boundaries. The habitat for this species is "nonwetland riparian" (Sackschewsky et al. 1992). Plants usually occur on cobble/stony soils in association with a number of other species. This variety of northern wormwood appears similar to other varieties of Artemisia campestris, but plants are generally smaller. Most importantly, the wormskioldii variety flowers in April, while other wormwood varieties flower during the summer months. Cobble/gravel bars located along the Hanford Reach within Site boundaries appear to provide suitable habitat for this species. Preliminary surveys of likely habitat (Figure 5) during the spring months of 1993 did not identify any populations on Site. Because of the rarity of this variety of wormwood, and the large amount of suitable habitat along the shoreline and islands of the Columbia River, special emphasis should be given to determine its status on the Hanford Site.

\section{Persistent Sepal Yellowcress}

Persistent sepal yellowcress occurs throughout the Hanford Reach, primarily downstream of Locke Island to the harchery at Ringold. During 1993, surveys for this plant were conducted by the DNR Natural Heritage Program in cooperation with PNL. A complete survey was conducted that included the shorelines of Benton and Franklin counties and of all the islands that occur in the Hanford Reach. The majority of plants occurred at six sites located at the downstream end of Locke Island and island 10 (Figure 6) at rivermiles 371 and 366 , respectively. Although stem densities reported previously for Hanford were generally higher than at a second downstream location on Pierce Island, below the Bonneville Dam (Gehring 1993), stem densities recorded during 1993 surveys were low (0.4 to 3.3 stems $/ \mathrm{m}^{2}$ ). Persistent sepal yellowcress occurs at the water shoreline interface. Abundance and distribution vary because of seasonal regulation of water flows released from the Priest Rapids reservoir.

\section{Bald Eagles, Canada Geese, and Hawks R. Mazaika}

\section{Bald Eagles}

Bald eagles are listed by the USFWS as threatened in the state of Washington. Historically, bald eagles have wintered along the Hanford Reach of the Columbia River. The majority of eagles occur between the Hanford Townsite and the 100-K Area. 


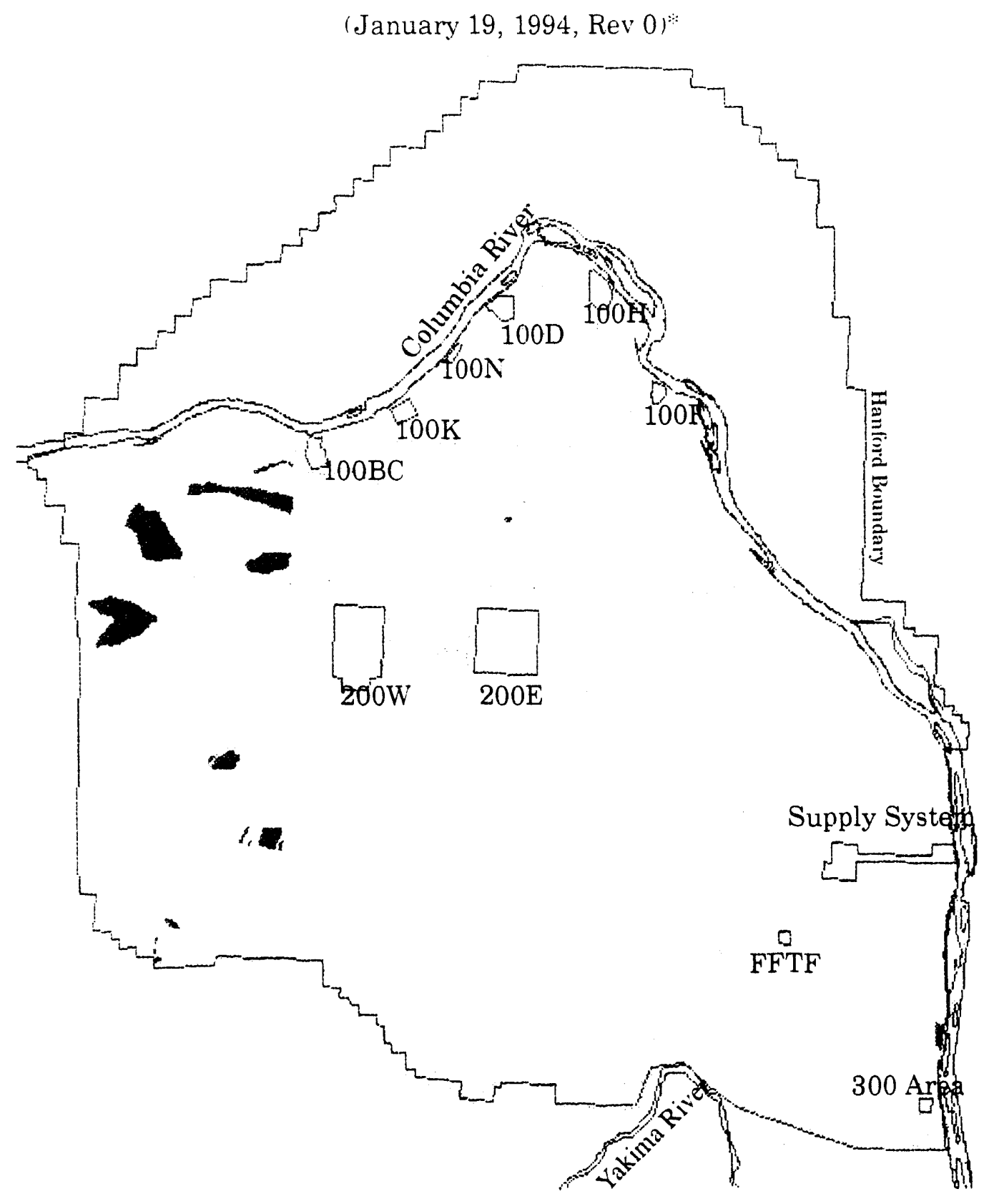

*Based on 1992-93 ground survey.

Map subject to revision as additional survey data become available.

Figure 4. Pygmy Rabbit Search Areas on Hanford Site, 1992-1993

We have monitored bald eagles since the early 1960s. Numbers of bald eagles and period of occurrence of wintering birds along the Hanford Reach vary with weather and food availability. Early records of numbers of these birds along the Hanford Reach are low
(Figure 7). Although bald eagle numbers increased during the $1970 \mathrm{~s}$, a positive response of birds relative to passage of the ESA cannot be assumed. Potential reasons for the observed increase in bald eagles through the 1970s and 1980s may include the added 


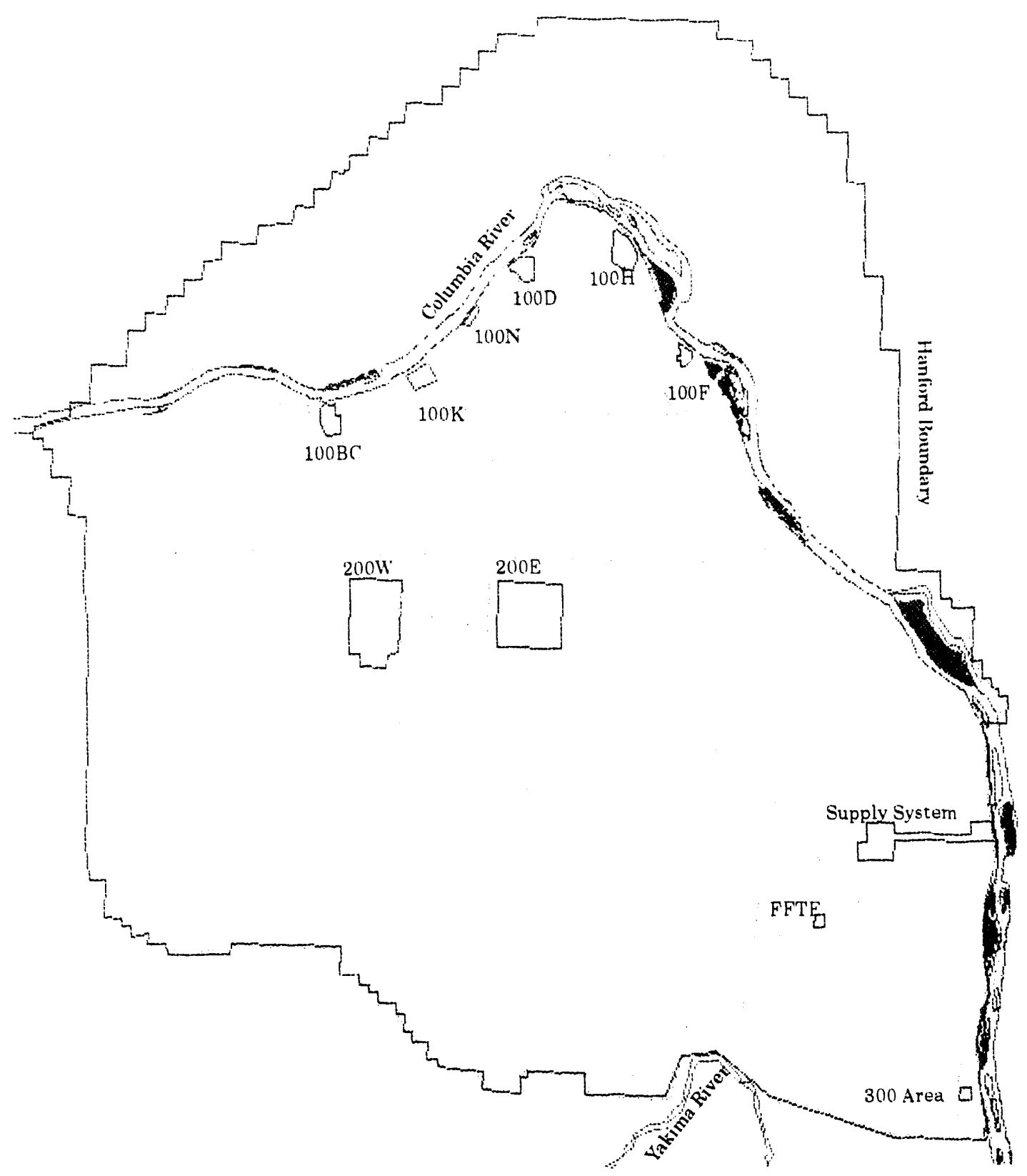

"Based on 199:3 ground surves:

Map subject to revision as additinnal surver data becomes available.

Figure 5. Northern Wormwood Search Areas on the Hanford Site, 1993

protection of bald eagles at nesting locations off of the Hanford Site and nation wide elimination of DDT as an agricultural pesticide. The maximum wintering population recorded during 1993 was 49 birds, observed during January.
Locally, one general assumption regarding changes in the number of bald eagles on the Hanford Reach is related to the number of salmon carcasses along the river shoreline. Salmon carcasses, as well as waterfowl, are a major winter food source of bald eagles. 


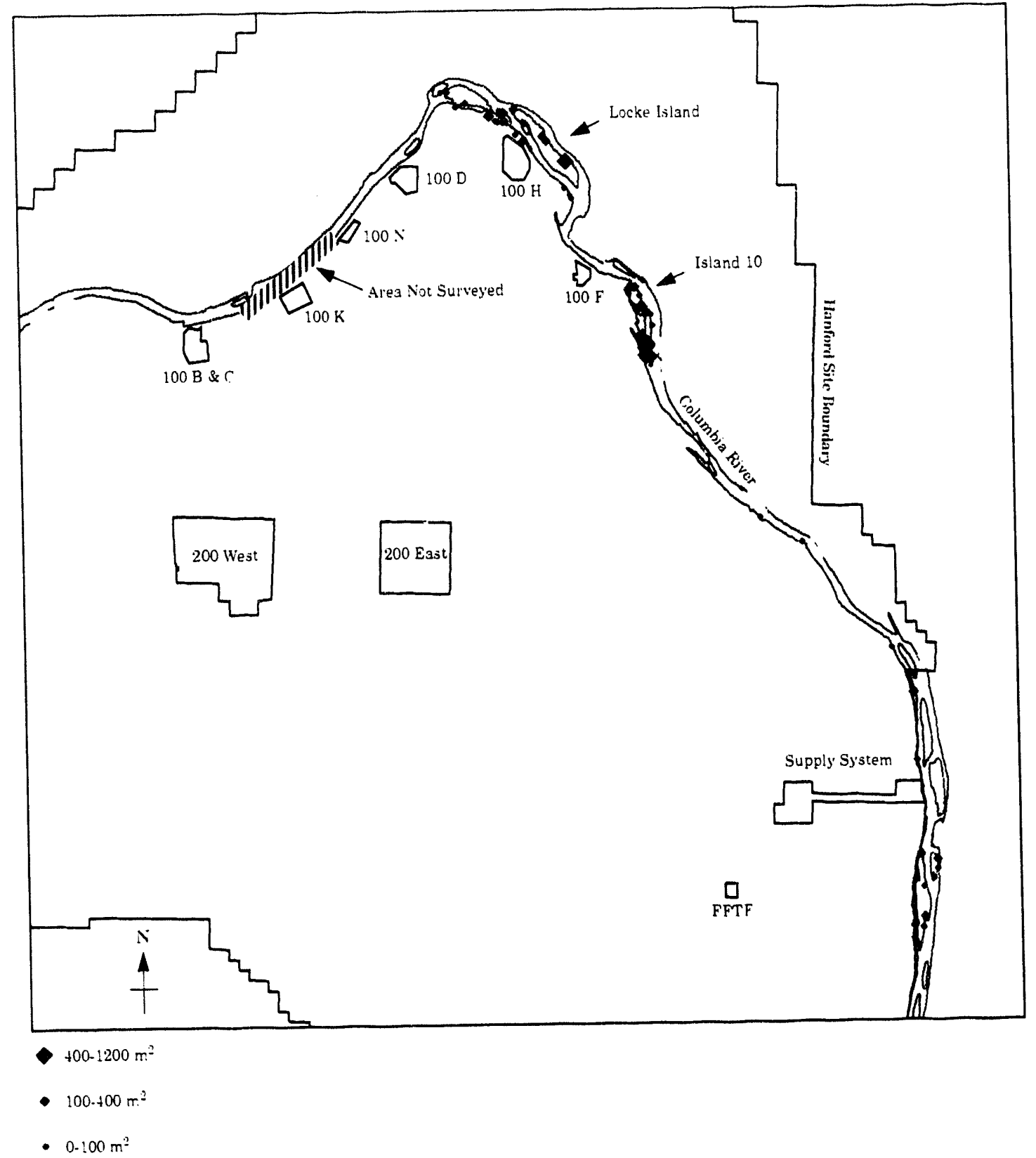

WDNR Survey Sites

Figure 6. Locations of Persistent Sepal Yellowcress Along the Hanford Reach, August-September, 1993

Currently, the population includes only wintering birds. Implementation of a plan that is being developed for the Hanford Reach, southcentral Washington, will facilitate establishment of nesting birds along the reach in the future. Elements of the management plan that will contribute to the species' success include maintaining night roosting, foraging, perching, and nesting habitat out of the range of human influence and ensuring the availability of food sources for the species. 


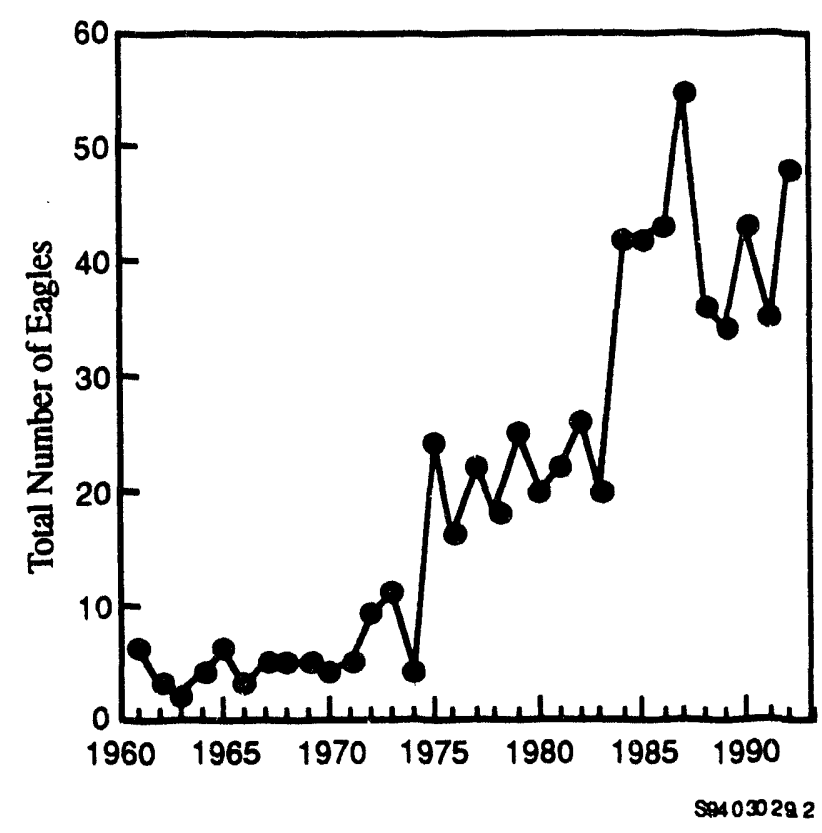

Figure 7. Bald Eagle Counts in the Hanford Reach, 1961-1992

\section{Canada Geese}

Nesting Canada geese are a valued aesthetic and recreational resource of the Hanford Reach. Nesting surveys have been conducted along the reach since 1950 in an effort to monitor changes in goose populations in response to reactor operations. Survey activities have been conducted relative to Hanford Site operations over the last 40 years, although activities of a different nature (e.g., hydroregulation of Columbia River flows) may result in similar consequences to geese.

The nesting population of Canada geese in the Hanford Reach has fluctuated during the last 40 years in response to coyote predation on upstream islands of the reach. Currently, the majority of goose nesting (i.e., $61 \%$ ) occurs on downstream islands within the reach. In 1993, 196 of 235 pairs nested successfully. That compares with 213 of 286 nesting pairs in 1992.

The success of geese in the downstream portion of the Reach may be attributed to a reduced coyote population among downstream islands or infrequent use of downstream islands by coyotes, associated with increased use of these areas by recreationists (e.g., hunters, fisherman). The suitability of habitat on islands for nesting Canada geese is attributed to restricted human use of islands during the nesting season, suitable nesting substrate, and adequate forage and cover for broods (Eberhardt et al. 1989).

\section{Hawks}

The undeveloped land of the Hanford Site provides nesting and foraging habitat for Swainson's (Buteo swainsoni), red-tailed (Buteo jamaicensis), and ferruginous hawks (Buteo regalis). These species rely on natural and human-made substrates across the Site for nesting. The nesting population of ferruginous hawks, a federal Candidate 2 species, represents $25 \%$ of the nesting population in the state of Washington. Recently, the number of nesting ferruginous hawks on the Hanford Site has increased, while nesting of red-tailed and Swainson's hawks, sympatric species that occur more frequently, has decreased. The reason for the decline has not been investigated.

\section{Bird Surveys W.R. Rickard}

Bird surveys on the Hanford Site are performed to determine species composition and relative abundance of wild birds in various habitats and to determine changes induced by wildfire or by those human activities associated with Hanford Site operations or by past agricultural practices.

\section{Shrub-Steppe Birds}

Surveys for shrub-steppe breeding birds are conducted in major shrub-steppe habitats using roadside survey methods. Survey lines are each $20 \mathrm{~km}$ long permanently marked at $0.8-\mathrm{km}$ intervals. All birds seen or heard during a 3-minute step are recorded. Surveys are conducted during spring months in early morning hours following the protocol described by the USFWS's breeding bird surveys.

Survey route "A" travels along the lower, gentle slopes of the Rattlesnake Hills and is located in sagebrush/bluebunch wheatgrass habitat (Figure 8). However, sagebrush is essentially missing because of recent wildfires. Survey route "B" travels along the Columbia River Plain. It passes through sagebrush-cheatgrass habitat. Although wildfires have destroyed many sagebrush shrubs, some of the most extensive patches of sagebrush on the Hanford Site are found along this route (Figure 8).

Survey route "C" also travels across the Columbia River Plain but mostly in sagebrush-bitterbrushcheatgrass habitat. Mature stands of sagebrush and bitterbrush along this route are confined to only a few small, scattered patches with most mature shrubs having been destroyed by recent wildfires. However, many young shrubs are present. Survey 


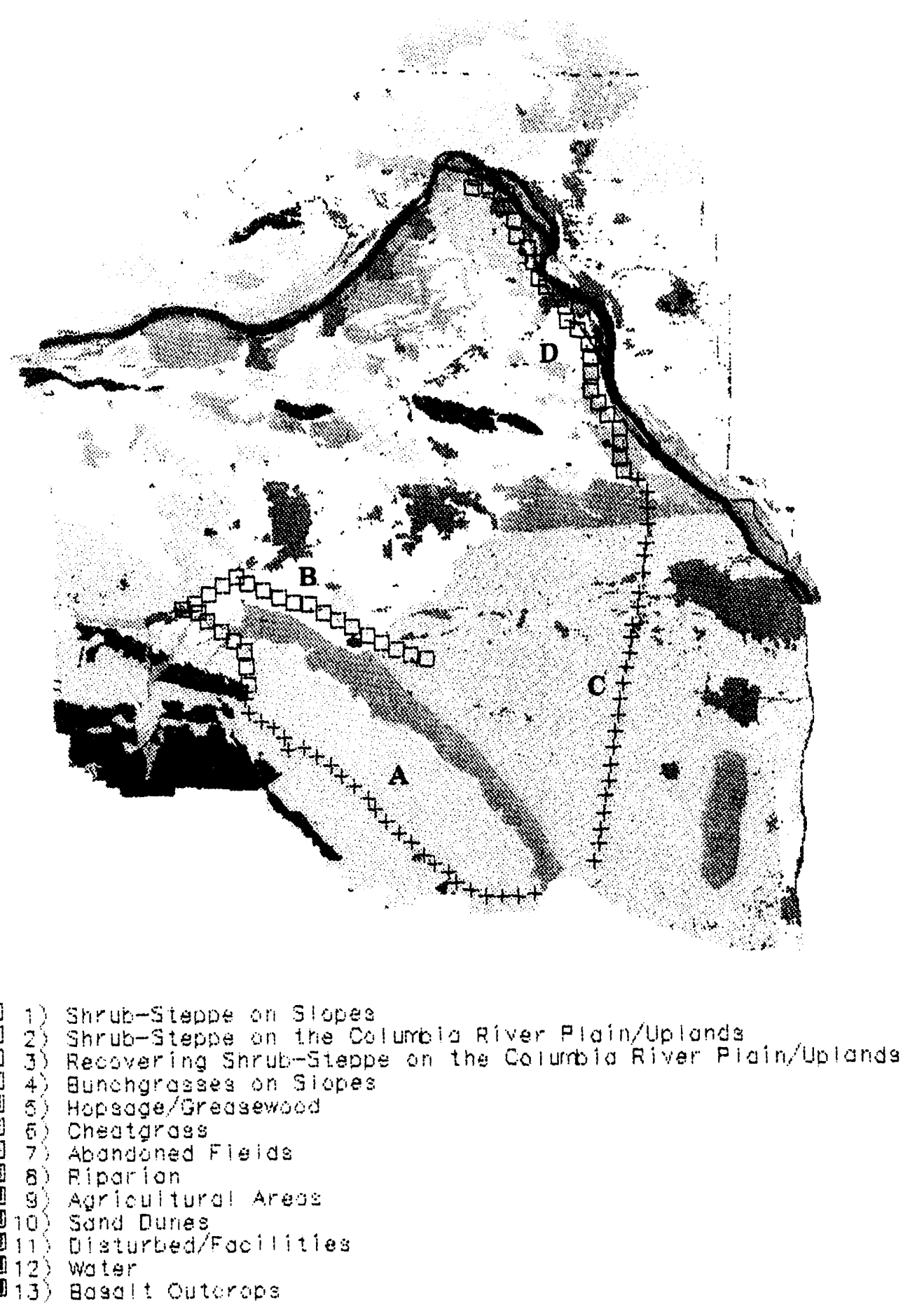

Figure 8. Survey Routes "A," "B," "C," and "D" for Breeding Birds on the Hanford Site

route " $D$ " travels mostly through a series of abandoned cultivated fields. These fields were abandoned in the early 1940s when the land was acquired by the federal government for inclusion in the Hanford Site. The $100-\mathrm{F}, 100-\mathrm{H}, 100-\mathrm{D}$, and $100-\mathrm{DR}$ reactors are located in abandoned field habitats. Shrubs are missing from old field habitats, and cheatgrass dominates the vegetative cover.
Plant species composition and canopy cover between bluebunch wheatgrass habitat and old field habitat were compared. Total canopy cover in the bluebunch wheatgrass habitat was $75 \%$ compared with $68 \%$ in the abandoned old field. Old field vegetation consists mostly of annual plants, mostly cheatgrass, while the dominant species in the bluebunch wheatgrass habitat are native perennials, mostly grasses. 
Shrub-steppe birds were recorded along the four survey routes in May 1993 (Table 3). Western meadowlarks (Sturnella neglecta) and horned larks (Eremophila alpestris) were the most numerous birds in all habitats. Long-billed curlews (Numenius americanus) were most numerous along survey route " $C$," and none were recorded along survey route " $A$." Vesper sparrows (Pooecetes gramineus) were recorded only along survey route "A." Lark sparrows (Chondestes grammacus) were not numerous and were recorded only along routes " $B$ " and "C." Loggerhead shrikes were most numerous along survey route " $B$," which supported the most extensive stands of sagebrush, and sage sparrows were recorded only along this survey route. A single sage thrasher was recorded along survey route "B."

The species composition and relative abundance of shrub-steppe birds varies across the Hanford Site according to topography and vegetation. The destruction of shrubs by wildfires and by past agricultural practices and construction activities makes the habitat unsuitable for those shrub-steppe birds that place their nests in shrub canopies, i.e., sage sparrow, sage thrasher, and loggerhead shrike. To restore these birds as nesters will likely require plantings of sagebrush and/or bitterbrush.

\section{Upland Game Birds}

Six species of upland game birds are known to inhabit the Hanford Site. These are the ring-necked pheasant (Phasianus colchicus), California quail (Callipepla californica), chukar (Alectoris chukar), gray partridge (Perdix perdix), mourning dove (Zenaida macroura), and sage grouse. Although sage grouse nested on the Hanford Site as late as the $1970 \mathrm{~s}$, broods have not been seen since that time. Chukars and gray partridges are present, but these were not recorded along the survey routes (Table 3 ). Mourning doves nest on the ground or in trees all across the Hanford Site, but none were recorded along survey route " $A$ " (Table 3). Ring-necked pheasants and California quail are closely restricted to riparian habitats, and most were recorded from survey route " $D$," which travels close to the shoreline of the Columbia River. Ring-necked pheasants and California quail have foraging access to the 100-Area reactor areas during all seasons of the year and have potential to ingest chemically contaminated foliage, seeds, and insects.

\section{Ravens and Magpies}

Common ravens (Corvus corax) and black-billed magpies (Pica pica) are widely distributed across the
Table 3. Numbers of Shrub-Steppe Birds Recorded Along Four Survey Routes "A," "B," "C," and "D," May 1993

Survey Routes

\begin{tabular}{|c|c|c|c|c|}
\hline Breeding Birds & A & B & $\mathrm{C}$ & $D$ \\
\hline \multicolumn{5}{|l|}{ Ground Nesters } \\
\hline Western meadowlark & 61 & 103 & 102 & 57 \\
\hline Horned lark & 70 & 24 & 70 & 78 \\
\hline Long-billed curlew(a) & 0 & 4 & 18 & 2 \\
\hline Vesper sparrow & 8 & 0 & 0 & 0 \\
\hline Lark sparrow & 0 & 1 & 2 & 0 \\
\hline Total & $\overline{139}$ & $\overline{132}$ & $\overline{192}$ & $\overline{137}$ \\
\hline \multicolumn{5}{|l|}{ Shrub Nesters } \\
\hline Loggerhead shrike ${ }^{(a)}$ & 0 & 9 & 2 & 0 \\
\hline Sage sparrow $(a)$ & $\underline{0}$ & 6 & $\underline{0}$ & 0 \\
\hline Sage thrasher $(\mathrm{a})$ & 0 & 1 & 0 & 0 \\
\hline Total & 0 & 16 & 2 & 0 \\
\hline \multicolumn{5}{|l|}{ Upland Game Birds } \\
\hline Ring-necked pheasant & 0 & 1 & 1 & 30 \\
\hline California quail & $\underline{0}$ & 0 & $\underline{0}$ & $\underline{8}$ \\
\hline Mourning dove & 0 & 9 & 1 & 3 \\
\hline Total & 0 & 10 & 2 & 41 \\
\hline
\end{tabular}

Common Ravens and Black-Billed Magoies

Black-billed magpie

Common raven

$\begin{array}{rrrr}\frac{0}{1} & \frac{6}{5} & \frac{2}{3} & \frac{5}{10} \\ 1 & 11 & 5 & 15\end{array}$

Total

(a) Species of concern to WDW.

Hanford Site. Magpies usually nest in trees, but ravens nest on artificial structures and steep cliffs, as well as in trees. These birds are predators and destroy eggs and nestlings of other species of birds. The numbers of magpies and ravens recorded along the survey routes are summarized in Table 3 . These birds have foraging access to the 100-Area reactor areas as well as other industrial facilities on the Hanford Site.

\section{Great Blue Herons}

Great blue herons (Ardea herodias) are fish-eating birds that nest in scattered colonies along the 
Columbia River. Over the last 20 years, the number of herons nesting along the Hanford Reach of the Columbia River has increased. In 1993, three colonies were located between the Hanford Townsite and White Bluffs. Two colonies were located in trees on the western shoreline one at the Hanford slough, the other at the White Bluffs slough. A third colony was located on the eastern shoreline, near the White Bluffs ferry landing. Two colonies were located far downstream in the vicinity at Ringold-one on Savage Island and the other on Plow Island. The Plow Island colony is unusual because the nests are placed on a steel electrical transmission line tower instead of in trees. This suggests that there are too few trees along the Hanford Reach located in protected areas to support additional heron colonies.

In the summer of 1992 a wildfire destroyed several trees at the Hanford slough colony. In 1993, this colony apparently relocated in a group of trees at the Hanford Townsite.

\section{Riparian Habitat Birds}

On the Hanford Site, native deciduous trees and shrubs grow only in narrow corridors along the wetted shorelines of the Columbia River and along small spring streams in the Rattlesnake Hills. These riprarian tree/shrub corridors provide habitats suitable for birds that do not nest in the surrounding desert shrub/grass-dominated habitats.

Surveys were made of a 2-ha isolated tree/shrub corridor along Snively Spring during winter 19921993 and spring 1993. This riprarian habitat differs from other similar habitats in the Columbia Basin because no resident human population has lived near the corridor for 50 years, and there has been no wood cutting, livestock grazing, or vegetative damage by spraying of chemical herbicides. We observed birds while slowly walking a $1-\mathrm{km}$-long path along the edge of the tree/shrub corridor. Only those birds that used the tree/shrub corridor for perching, foraging, or cover were reported. The average number of birds recorded by species per survey and the frequency of occurrence (percentage of surveys in which a species was observed) are shown in Table 3.

Ten bird species were seen during five winter surveys. Of these only the American robin (Turdus migratorius), black-billed magpie, song sparrow (Melospiza melodia), and dark-eyed junco (Junco hyemalis), were seen on $40 \%$ or more of the surveys. The 1992-1993 winter was marked by the heaviest snowfall during the 50-year history of the Hanford Site. Snow cover was present during all surveys except the first one. California quail were seen on the first survey, but none were seen thereafter. Chukars were seen only on one survey, but patches of chukar feathers in the snow indicated that chukars were vulnerable to avian predators, perhaps great horned owls (Bubo virginianus).

Eighteen bird species were either known nesters or thought to be nesters in the tree/shrub corridor in spring 1993. Of these, the Brewer's blackbird (Euphagus cyanocephalus), mourning dove, blackbilled magpie, northern oriole (Icterus glabula), lazuli bunting (Passerina amoena), orange-crowned warbler (Vermavora celata), eastern kingbird (Tyrannus tyrannus), western kingbird (Tyrannus verticalis), and western wood pewee (Contopus sordidulus) were seen on $40 \%$ or more of the seven surveys. Although one pair of red-tailed hawks built and defended a tree nest, no young birds were produced.

Three bird species were identified as being especially amenable to long-term monitoring of changes in nesting abundance. These were the northern oriole, black-billed magpie, and eastern kingbird. Their nests are either relatively conspicuous, or the parent birds exhibit conspicuous behavior during the nesting season.

\section{Mule Deer}

\section{B.L. Tiller}

Mule deer (Odocoileus hemionus) are common residents of the Hanford Site and are important because of the recreational (offsite hunting) and aesthetic values they provide. Because mule deer have been protected from hunting on the Hanford Site for approximately 50 years, the herd has developed a number of unique population characteristics that are in contrast to most other herds in the semiarid region of the Northwest. These characteristics include a large proportion of old animals and large-antlered males. This herd provides an opportunity for comparison to other more heavily harvested herds in this region. A study of the herd was initiated in 1990 because of its unique nature and the high degree of public interest.

\section{Population Estimation}

As part of the Wildlife Resources Monitoring Project, we monitor populations of wildlife species of special concern (e.g., those classified as threatened or endangered and those that receive much public interest). Mule deer fall into the latter classification. 
However, we have no reliable estimates of the number of deer that reside on the Hanford Site. We do know that the 100 Areas and other locations adjacent to the Columbia River support the largest number of deer on the Site. By marking a sufficient number of deer with radiocollars and conducting surveys, we plan to estimate the population of deer residing along the Hanford Reach. Actual deer surveys as part of the population estimation are scheduled for 1994.

\section{Movement Patterns}

Based on previous tagging of fawns along the islands and radiocollaring of adult deer in the 200 Areas, we know that some Hanford Site deer move off site and are harvested by hunters. By marking several deer with radiocollars and routinely relocating these animals, we can determine the extent and frequency of deer movements to islands on the Columbia River and areas across the river, including the Wahluke Slope Wildlife Recreation Area and private property where they are available to legal hunting. This effort will complement efforts described above. The GIS is being used to quantify the frequency and extent of offsite movements.

More than 1300 location coordinates on 32 of these radiotagged deer have been systematically collected throughout the last 2 years. Frequent movements were made by some deer, particularly during breeding and fawning (October-December and May-June). The extent of offsite movement by radiotagged deer, in general, has been small as the most frequently visited locations occur immediately adjacent to the Hanford Site along the riparian edge of the Columbia River. However, some movements have occurred approximately 5 miles from the Columbia River. Figure 9 illustrates the sighting locations of radiotagged deer relative to where the animals were captured.

\section{Strontium-90 in Antlers}

Mule deer are of interest to radiation monitoring programs because they can provide useful information relating to contaminated sites and subsequent clean-up efforts (Eberhardt and Cadwell 1983). Additionally, mule deer are often hunted and eaten and can contribute to the annual radiation dose received by a private citizen (Soldat et al. 1990).

The routine method for monitoring deer for radionuclide contamination on the Hanford Site is to collect samples from deer killed on the roads. Usually only two to three samples are collected each year, and often these deer are collected in areas distant from contaminated sites. The objective of this effort is to sample a relatively large number of deer residing near 100-Area facilities in a nondestructive manner. Strontium-90 concentrations in deer antlers have been shown to be reflective of ${ }^{90} \mathrm{Sr}$ levels in bone tissue because of translocation of calcium from bone to antlers during growth (Schultz 1964; Schreckhise 1974).

During deer capture events in late winter/early spring, a portion of male deer antler is removed and submitted for ${ }^{80} \mathrm{Sr}$ analysis. Some of the sampled male deer have been tagged with solar-powered ear radiotransmitters and released for subsequent tracking. In this way, it is possible to evaluate the animals' area of use and the corresponding ${ }^{90} \mathrm{Sr}$ results.

From 1991 through 1993, mule deer captures were conducted at four locations near the 100-Area facilities and at three locations between the old Hanford Townsite and the 300 Area (see Figure 10). During the capture events, 13 antler samples were collected for ${ }^{90} \mathrm{Sr}$ analysis. For comparison, six shed antlers were also collected in the same areas and analyzed for ${ }^{90} \mathrm{Sr}$. Results of analyses from the antlers sampled from live deer and the shed antlers samples are summarized in Figure 10.

\section{Gonadal Atrophy}

Our observations made during capture events for mule deer during February and March 1991 and 1992 revealed that four (of 18) of the adult bucks had atypically shaped antlers that were velvet covered. Those animals also lacked normally developed testicles. When testicles were evident, they appeared smaller in size than in males having normally developed antlers.

Similar anatomical conditions in deer have been reported from other areas in the United States. For example, a similar occurrence was documented in white-tailed deer in southcentral Texas, but no causeeffect was determined (Taylor et al. 1964). It was found that as many as $7.3 \%$ of bucks harvested from this area had the $r$ ascribed anomaly. The researchers sectioned the affected testicles and found that the seminiferous tubules were inverted, indicating atrophied (shrunken) as opposed to hypoplastic (incompletely developed) testicles. Clark (1953) reported that deer with abnormal antler growth and retained velvet were fairly common in Arizona and were known as "cactus bucks." The testes of these bucks were "the size of an average marble and almost as hard." 


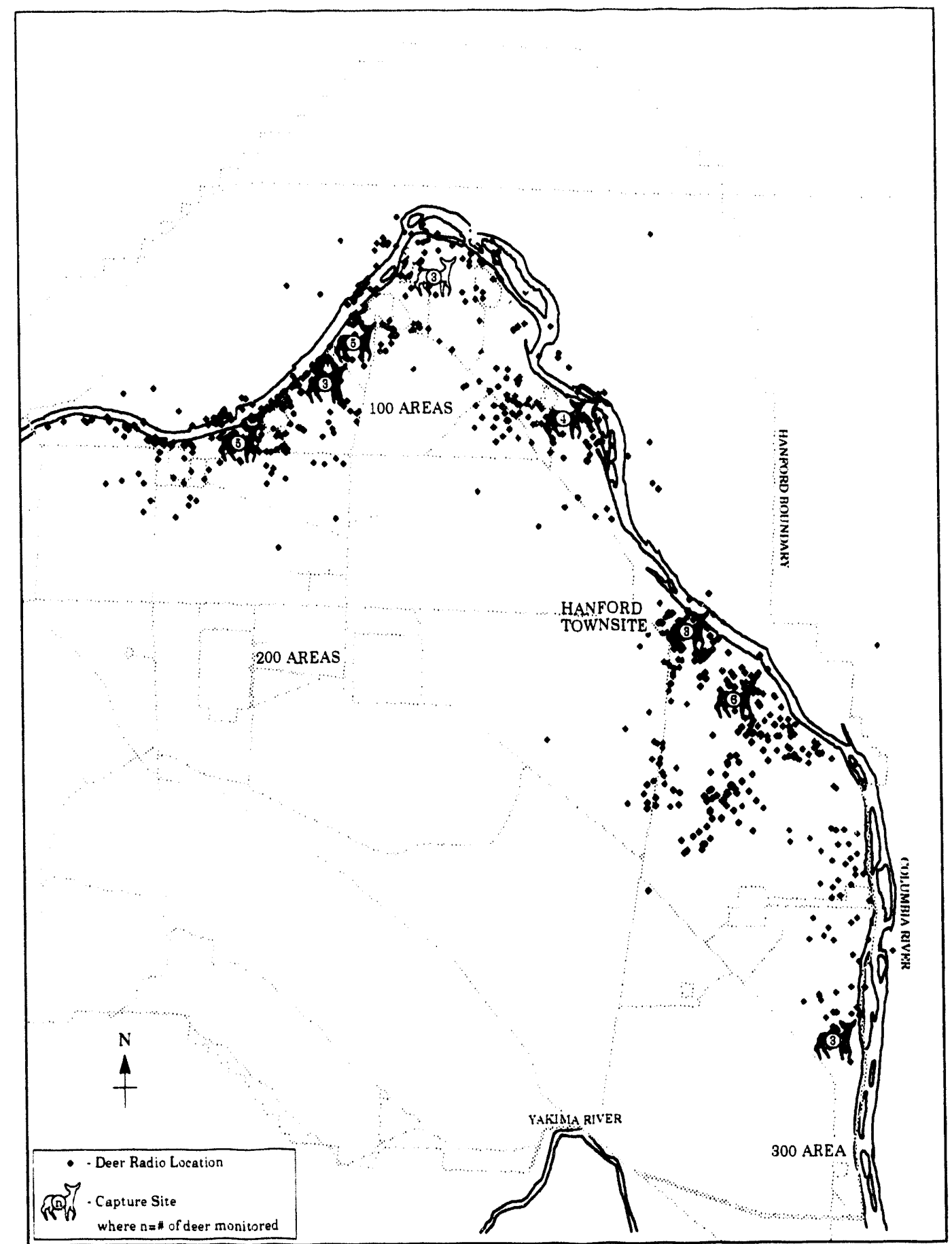

Figure 9. Hanford Deer Locations Relative to Capture Sites, 1991-1992

In 1993 we collected tooth, blood, and testicular samples from Hanford Site mule deer during the spring capture event to attempt to identify reasons for the observed anatomical abnormalities. Aging of male deer from tooth cementum analysis indicated that affected deer were older than non-affected deer, but the sample size was generally too small to draw conclusions about age versus anatomical condition. Analysis of testicular samples indicated that the testicles of affected animals had developed normally and then subsequently atrophied (regressed after initial development rather than incompletely developed). The affected animals, thus, were determined to be permanently sterile. 


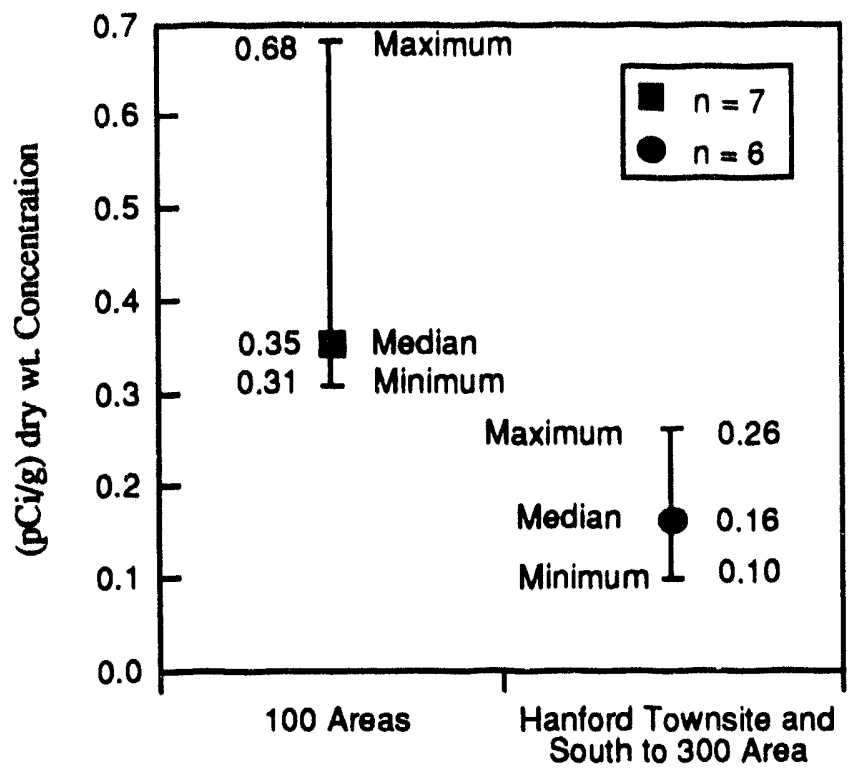

a) Strontium-90 Concentrations in Deer Antlers Collected in 1991,1992, and 1993

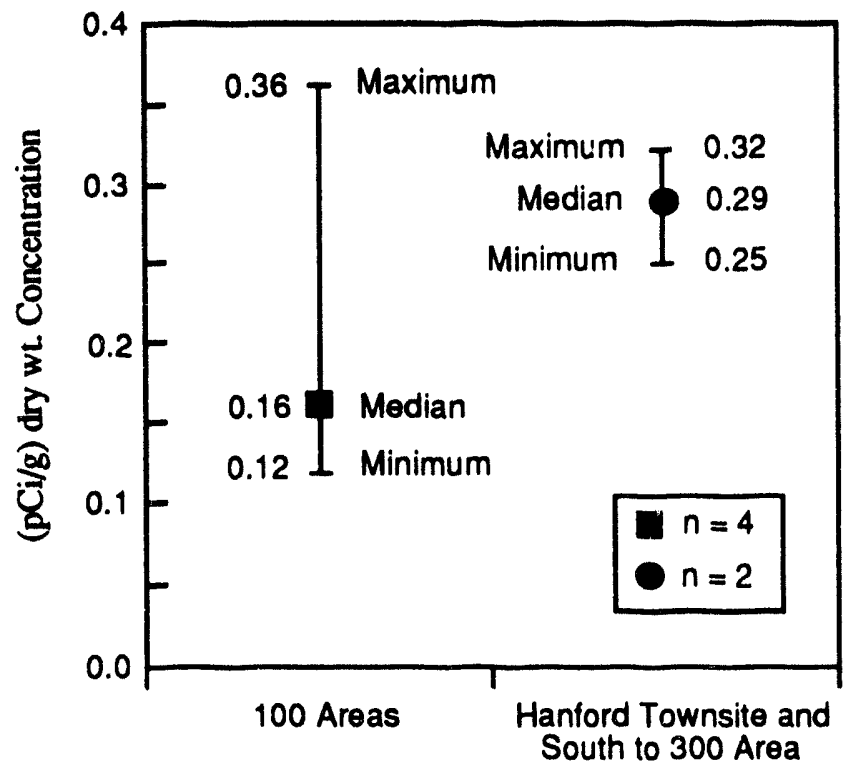

b) Strontium-90 Concentrations in Deer Antlers from Years Prior to 1990 (Collection Year)

59403029.3

Figure 10. Strontium-90 Concentrations in Deer Antlers

Blood samples taken from females, however, indicated that all were pregnant, suggesting that female deer are not reproductively impaired, as are some of the older males. The pregnancy data also indicate that herd reproduction has not been reduced by the reproductive impairment of some of the males.
Additional sampling and analyses are planned for 1994 to further investigate potential causes for the observed anatomical and reproductive abnormalities observed in some of the older male deer.

\section{Rocky Mountain Elk \\ B.L. Tiller}

\section{Population Census}

Rocky Mountain elk (Cervus elaphus nelsoni) appeared on ALE in winter 1972. Five animals stayed and reproduced, increasing the population to 133 animals after the 1991 calving season. Relatively few animals are harvested on private lands adjoining the Fitzner/Eberhardt ALE Reserve each year, and consequently, hunter harvest has not had a significant impact on the population size in the last several years. In 1992, the elk population increased to 190 animals (post-calving census) (Figure 11). Seven adult bulls were harvested during the 1992 offsite hunting season, and one adult bull was killed by a car on Highway 241. Post-calving census efforts are currently underway for 1993.

A total count of elk is determined each year by conducting a series of aerial surveys during the post-calving period (August to September) and the post-hunting period (December to January). Radiotransmitters are placed on elk to aid researchers in locating the animals for the population census.

An elk capture was conducted in spring 1993 to fit additional elk with radiotransmitters to continue to conduct a census of the herd and initiate a special population study. Twenty animals were subdued by a tranquilizer dart shot from a helicopter. The anesthetized animals were then aged, measured, checked for pregnancy, fitted with radiocollars, and released. The average age of these animals was found to be 4 years old, with the oldest animal being 14 years old. All but one of the females were found to be pregnant, indicating a healthy herd and an adequate number of bulls to maintain the herd at full reproductive capability. Table 4 summarizes the sex and age breakdown of the elk population over the last 10 years.

Elk are successful on the Fitzner/Eberhardt ALE Reserve because of 1) available forage without competition from domestic livestock; 2) unrestricted access to drinking water at springs located on ALE; 3 ) relatively mild winters; 4) ability to accommodate extreme summer temperatures, even in the absence of shade; and 5) absence of hunting on the Site. 


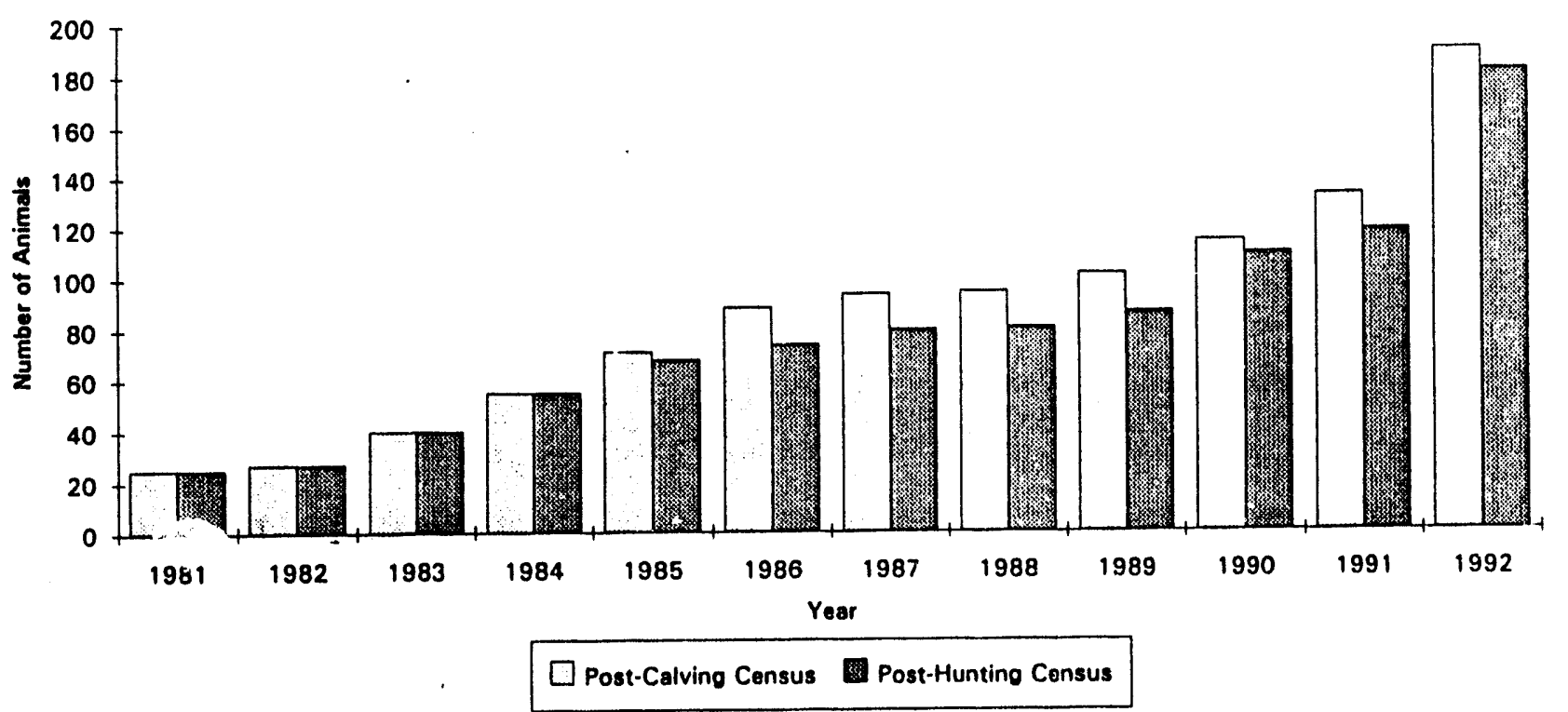

Figure 11. Elk Population (Post-Calving and Post-Hunting Census) Observed on the ALE Site

Table 4. Age and Sex Classification of Elk Herd (Post-Calving) on the Fitzner/Eberhardt ALE Reserve

Total Adult Yearling Adult Yearling

\begin{tabular}{|c|c|c|c|c|c|c|}
\hline Year & Number & Male & Male & Female & Female & Calves \\
\hline 1983 & 40 & 5 & 3 & 16 & 3 & 13 \\
\hline 1984 & 55 & 7 & 12 & 20 & 1 & 15 \\
\hline 1985 & 71 & 18 & 7 & 21 & 8 & 17 \\
\hline 1886 & 89 & 22 & 8 & 29 & 9 & 21 \\
\hline 1987 & 95 & 15 & 5 & 32 & 16 & 27 \\
\hline 1988 & 99 & 12 & 13 & 38 & 13 & 23 \\
\hline 1989 & 102 & 18 & 10 & 40 & 11 & 23 \\
\hline 1990 & 115 & 22 & 12 & 49 & 11 & 21 \\
\hline 991 & 133 & 17 & 11 & 72 & 10 & 23 \\
\hline 1992 & 190 & 30 & 11 & 93 & 12 & 44 \\
\hline
\end{tabular}

\section{Elk Population Studies}

\section{B.L. Tiller}

\section{Background}

The manipulation of reproduction in wildlife populations has been explored by biologists and physiologists for nearly 30 years. Most of these studies have been unsuccessful, inconclusive, or used contraceptive techniques that were impractical for large-scale applications. During the last 5 years, however, several contraceptive technologies have been developed that have proven to be both successful at inhibiting reproduction and practical for application to wild populations. These results have stimulated an increase in interest and research by a wide variety of federal agencies and academic institutions. Although research is accelerating, all studies to date have focused on evaluating the efficacy of contraceptive technologies on individual captive or free-roaming animals. These studies continue to provide useful information, but the ability of remotely administered contraceptives to limit population growth in wild ungulates has not been determined.

One method, the zona pellucida vaccine, relies on an immunological response that prohibits the sperm from penetrating the acellular glycoprotein layer surrounding the mammalian oocyte (zona pellucida), thus blocking fertilization. Vaccine developed from a pig ovary extract (PZP-porcine zona pellucida) has proven to be an effective contraceptive for a variety of mammals including feral horses, white-tailed deer, and numerous exotic ungulates held in zoos. A major advantage of the PZP vaccine is that animals are treated through an injection, which allows the vaccine to be delivered remotely by dart. Treated animals pose no threat to the food chain as neither the antigen nor the antibodies produced against it can survive digestion after oral ingestion; hence, the vaccine is very safe. 
One possible drawback of the PZP vaccine is the potential for the disruption of the normal breeding season. Because the vaccine only blocks fertilization, treated animals may continue to cycle and come into heat numerous times before photoperiod suppresses the reproductive cycle. Another disadvantage of the PZP vaccine is that it is only effective for a single year; thus, animals must be treated annually. Microencapsulation and microsphere technologies are currently being explored and promise to provide a single-dose vaccine in the near future that would be effective for several years.

\section{Study Plan}

PNL biologists and Dr. Robert Garrott, University of Wisconsin, have initiated a population-level experiment using the ALE elk population. This experiment was designed to evaluate a method of remote inoculation (not handling the animals), test its effectiveness in wild populations, determine the reproductive behavior of treated animals, and compare the population response to predictive population growth model results. Ten female elk were treated with the vaccine, and an additional 10 animals will serve as a control group.

The elk population residing on ALE provides a nearly ideal test population for determining populationlevel and behavioral response to the immunocontraception technique. The population has been monitored sunce its establishment on ALE in 1972, providing data on reproduction, survival, movements, and population growth rates that are essential to the development of a realistic demographic immigration and emigration confounding a population-level experiment.

The current size of the herd ( 170 to 200 ) is optimal for a realistic test of the contraceptive vaccine. The physiography and plant communities of ALE are other key attributes that will contribute to the success of this research. The relatively gentle topography and lack of overstory vegetation provides opportunities for locating, treating, conducting censuses, and observing the animals' behavior that are not possible in forested, mountainous terrain. Lack of hunting and other major human disturbance also permits elk population dynamics and elk behavior in response to immunocontraception to objectively evaluated.

\section{Historical Database M.A. Simmons}

Large amounts of data have been gathered on Hanford Site wildlife over the last 40 years.
Unfortunately, much of these data were not in a format that was easily accessible or understandable to any but those responsible for collecting the data. Additionally, many people involved in the collection of the data are no longer at PNL. Thus, a wildlife resources database was developed and implemented to maximize the usefulness of historical wildlife data sets and more effectively manage and track data and information on wildlife censuses, sensitive species and habitats, and related reports and publications.

Some long-term monitoring on the Hanford Site includes censuses of salmon spawning (from 1948), Canada goose nesting (from 1953), bald eagles (1961), breeding hawks (1975), and documentation of the establishment of an elk herd on the Fitzner/ Eberhardt ALE Reserve (1975). The length and consistency of these records is unusual, and they will make useful contributions to the maintenance of these species and the environment.

\section{Approach}

A data management system was developed that will provide easy input and access of the data. A twopart system was developed, with the researchers responsible for inputting the data into a computer format of their own choosing, and the database manager responsible for inputting the formatted data into the database and setting up the query system for retrieval. The system was designed so data input for the researcher was a natural part of the study, with the format reflecting the analysis or presentation methods used by the researcher. Documentation was taken from the research proposal, work scope, or paper. When the data collection/ analysis is completed and verified, the data and documentation is then transferred to the database.

For the second part of the system, the database manager builds a shell to accommodate the data and allow for easy access. The manager is also responsible for making the system secure. In the database, data are indexed according to type, species, location, and researcher. The data are then available as a summary or as individual records. Further, the system is connected to an optical disk storage system for backup.

\section{Database System}

Table 5 lists the data sets that are being entered or will be entered in to the database. During 1993, most data going into the system were historical studies and current-year monitoring work with salmon, Canada goose nesting, breeding bird surveys, 
Table 5. Data Sets to Be Included in a Hanford Site Wildlife Database

1994

Estimated

Date

Period Covered

Data Set

\section{Census Data}

Breeding bird survey

Old-field vegetation study

Nesting Canada geese

Wintering bald eagles

Breeding hawks

Elk

Beetles

Nㅗ 1988-present

1992

1953-present

1961-present

1975-present(a)

1982-present

1963-present

1947-present

1988-1989

1986-1987

\begin{abstract}
1975-present
1973-present(a)

1980-present

1982-present

1992-present
\end{abstract}

Status: In Computer Format

Documentation

Years Entered

1988-1991

1992

1957-1993

1961-1993

1975-1993

1983-1993

1964-1979

1948-1993

Done

Done

Done

May

August

August

May

1988-1989

1986-1987

1975-1993

data located

1983-1993

\section{Status: In Database \\ Completed \\ Started Documentation}

$x$

$x$

1992-1993

1985-1989

1979 $x$

$\mathbf{x}$

$x$

$x$

Data

1988-1991

1992

1957-1993

1947-1993

$x$
$x$

$x$
$x$

$x$

$1988-1991$
$1985-1989+$

1979

Done

Done

Rattlesnake Springs

Chemistry

(a) Data were not gathered during some years. 
wintering bald eagles, and elk and deer census. Locational data includes nesting hawks, eagle roosts, shrike nests, and deer and elk ranges.

Reflecting the change in mission at Hanford, new data sets include habitat surveys and locational data on rare and sensitive plant and animal species, such as Rorippa calcycina var. columbiaea, Columbia River mollusks, pygmy rabbit, and northern wormwood.

The database comprises five sections: 1) study site, 2) study summary, 3) data sets, 4) publications, and 5) investigator profiles, which are described below.

1. The study site consists of a map and information about the area. Currently, the database includes maps of ALE and the Hanford Site. In the future, information about specific research locations will be added.

2. The study summary contains documentation for a study. It includes the rationale, procedures, any references, contact, pertinent Laboratory Record Books, and location of hard copies of the data.
3. Actual data records can be accessed under data sets, and many options exist for viewing (or sorting) the data. It is also possible to translate codes.

4. Publications can be searched by author and key words.

5. Author profiles or resumes can be accessed.

The database software also stores photographs and GIS maps. A pictorial database will be added to identify plant and animal species as well as study locations.

\section{Usage}

We are currently making data available to the DOERichland Operations Office and WDW for land-use decisions. Data from Hanford are providing information on wintering bald eagle habitat, loggerhead shrike nesting locations, and elk and deer home ranges. The wildlife resources database will be used to compile the data for transfer to the Hanford Environmental Information System (HEIS). 


\section{References}

Clark, E.D. 1953. A Study of the Behavior and Movements of the Tucson Mountain Mule Deer. Masters Thesis, University of Arizona, Tucson, Arizona.

Eberhardt, L.E., and L.L. Cadwell. 1983. "Radiotelemetry as an Aid to Environmental Contaminant Evaluation of Mobile Wildlife Species." Environ. Monit. and Assess. 4:283-289.

Eberhardt, L.E., R.E. Anthony, and W.H. Rickard. 1989. "Survival of Juvenile Canada Geese During the Rearing Period." J. Wildlife Manage. 53:372-377.

Gehring, J.L. 1993. Growth and Reproduction of Rorippa columbiae on the Columbia River in 1992. The Nature Conservancy, Seattle, Washington.

Sackschewsky, M.R., D.S. Landeen, G.I. Baird, W.H. Rickard, and J.L. Downs. 1992. Vascular Plants of the Hanford Site. WHC-EP-0554, Westinghouse Hanford Company, Richland, Washington.

Schreckhise, R.G. 1974. Strontium Kinetics in Mule Deer. Ph.D. Dissertation, Colorado State University, Fort Collins, Colorado.
Schultz, V. 1964. "Sampling White-Tailed Deer Antlers for Strontium-90.” J. Wildlife Manage. 28(1);43-49.

Soldat, J.K., K.R. Price, and W.H. Rickard. 1990. Methodology Used to Compute Maximum Potential Doses from Ingestion of Edible Plants and Wildlife Found on the Hanford Site. PNL-7539, Pacific Northwest Laboratory, Richland, Washington.

Taylor, D.O.N., J.W. Thomas, and R.G. Marburger. 1964. "Abnormal Antler Growth Associated with Hypogonadism in White-Tailed Deer in Texas." Amer. J. Vet. Res. 24:179-185.

Washington Department of Wildlife (WDW). 1993. Status of the Pygmy Rabbit (Brachylagus idahoensis) in Washington. Washington Department of Wildlife, Olympia, Washington. 


\title{
Appendix A
}

\author{
Endangered, Threatened, and \\ Candidate Species of the Hanford Site
}




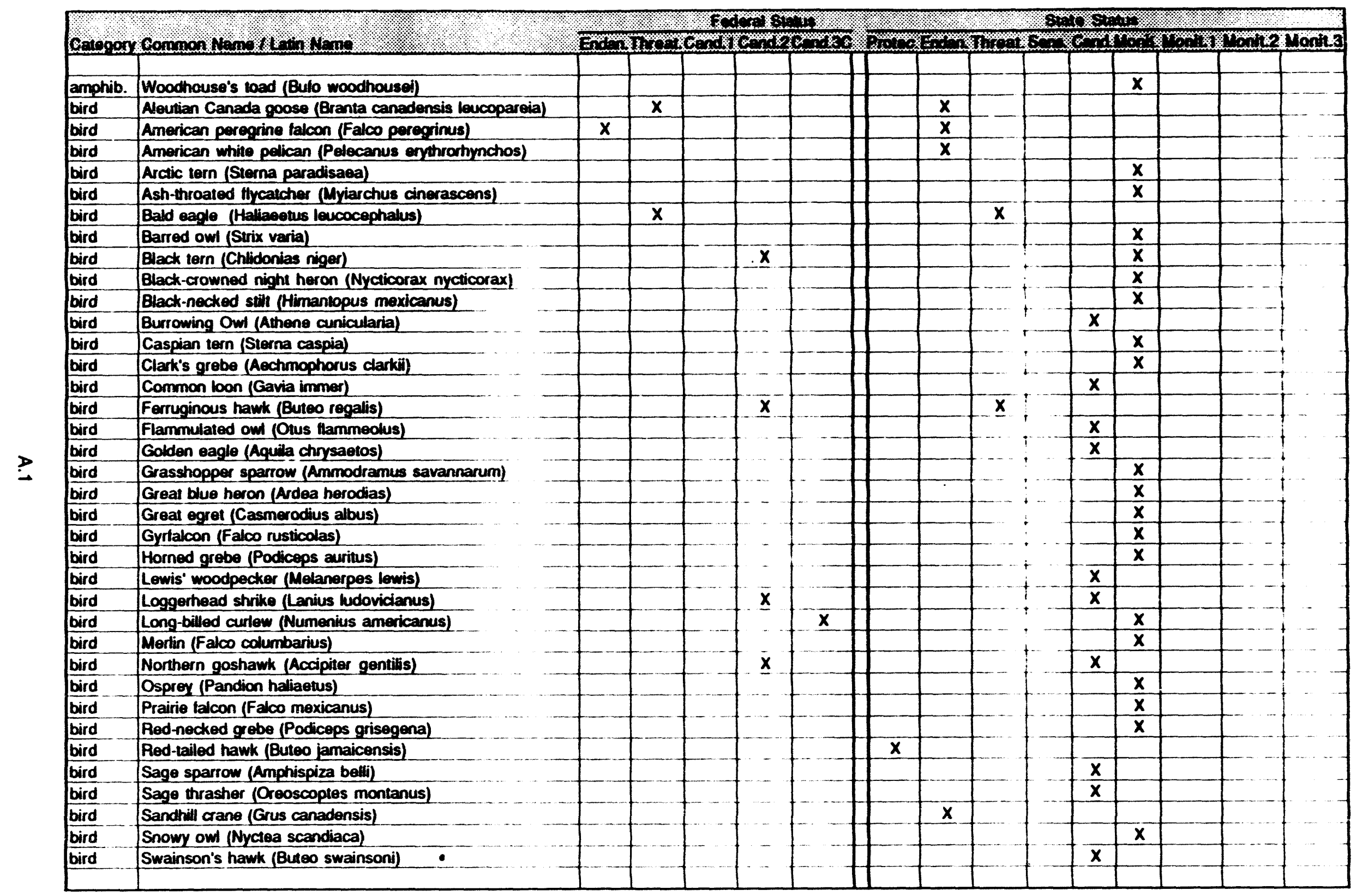




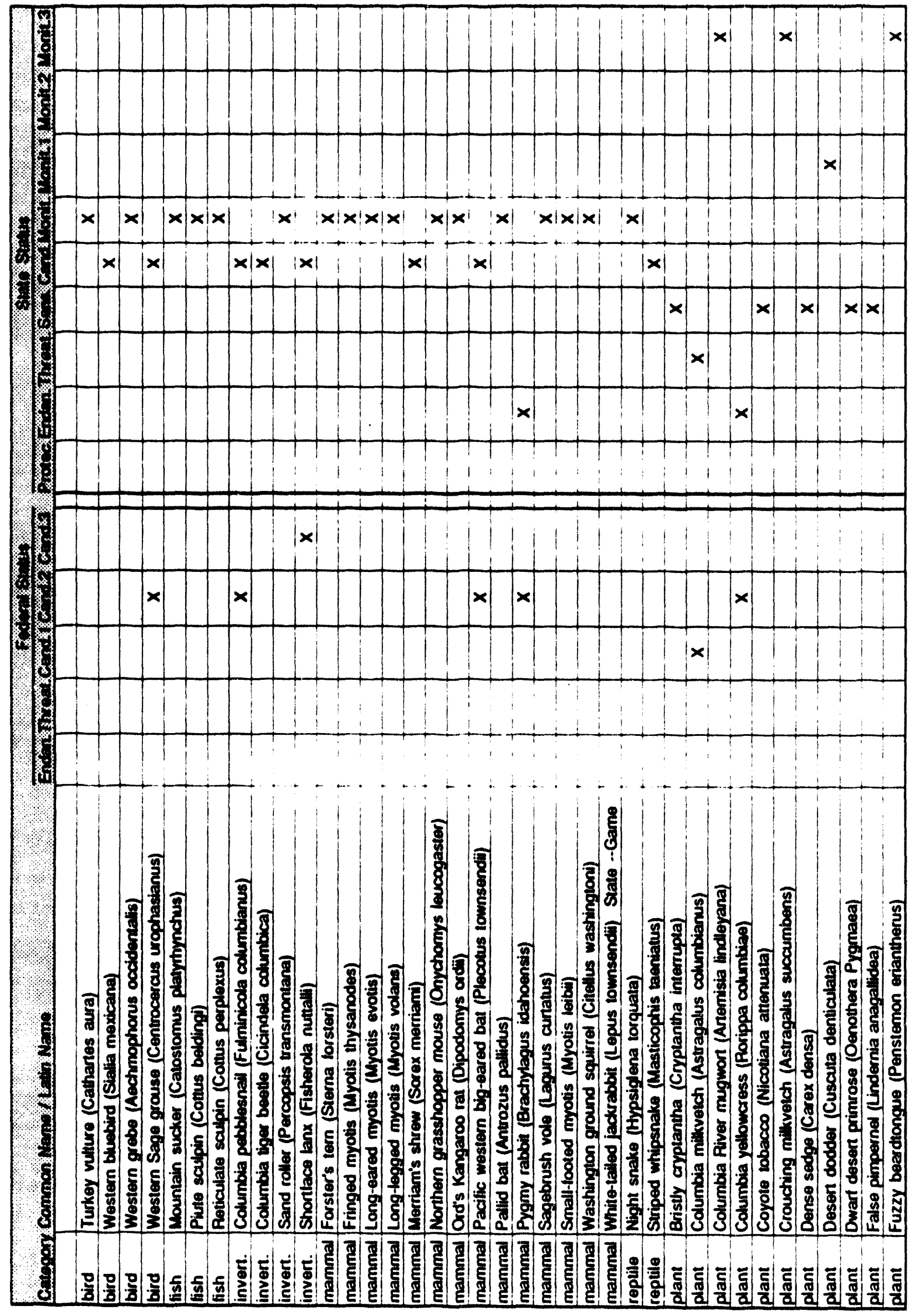




\begin{tabular}{|c|c|c|c|c|c|c|c|c|c|c|c|c|c|c|}
\hline \multirow{2}{*}{\multicolumn{2}{|c|}{ 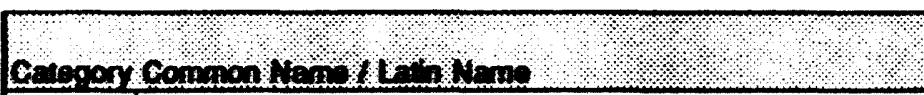 }} & \multicolumn{4}{|c|}{ 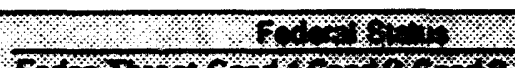 } & \multicolumn{9}{|c|}{ 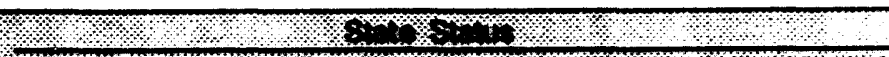 } \\
\hline & & \multirow{2}{*}{\multicolumn{4}{|c|}{ 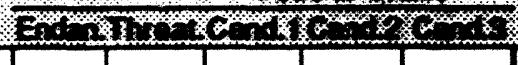 }} & \multirow{2}{*}{\multicolumn{3}{|c|}{ | }} & \multirow{2}{*}{\multicolumn{3}{|c|}{10}} & \multirow{2}{*}{\multicolumn{3}{|c|}{ Thing }} \\
\hline & & & & & & & & & & & & & & \\
\hline plant & Gray cryptantha (Cryptantha loucophaea) & & & & & & & & $\bar{x}$ & & & & & \\
\hline plant & Hoover's desen parsloy (Lomatium tuberosum) & & & $\bar{x}$ & & & & $\underline{x}$ & & & & & & \\
\hline plant & Medick millkvelch (Astragalus speirocarpus) & & & & & & & & & & & & & $\underline{x}$ \\
\hline plant & Marthern wormmood (Antemisia campestris ssp. borealis ve & r. mormskioldifit & $\underline{x}$ & & & & $\bar{x}$ & & & & & & & \\
\hline plant & Palouse milkvelch (Astragalus arrectus) & & & & & & & & $x$ & & & & & \\
\hline plant & Palouse thistle (Cirsium brovifolium) & & & & & & & & & & & & & $\mathbf{x}$ \\
\hline plant & Piper's daisy (Erigeron piperianus) & & & & & & & & $x$ & & & & & \\
\hline plant & Robinson's onion (Mimum robinsonii) & & & & & & & & & & & & & $\bar{x}$ \\
\hline plant & Plosy balsamroof (Balsamorhiza rosea) & & & & & & & & & & & & & $\underline{x}$ \\
\hline plant & Shining latsedge (Cyperus rivularis) & & & & & & & & $x$ & & & & & \\
\hline plant & Smooth ciffltorako (Pelaba glabella) & & & & & & & & & & & & & $\underline{x}$ \\
\hline plant & Southern mudwort (Limosella aquatica) & & & & & L & & E & $\mathbf{x}$ & & & 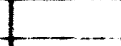 & - & \\
\hline plant & Squill onion (Alium scillioides) & & & & & & & & & & & ـ & $\ldots$ & $\underline{x}$ \\
\hline plant & Stalked-pod millivelch (Astragalus sclerocarpus) & & & & & & & & & & & - & 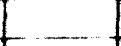 & $\underline{x}$ \\
\hline plant & Thompson's sandwon (Arenaria tranklinii var. thompsonii) & & & & & & & & & & & & $\mathbf{x}$ & \\
\hline
\end{tabular}


No. of

Coples

Offaite

12 DOE/Office of Scientific and Technical Information

J. Annear

Umatilla National Wildlife Refuge

P.O. Box 700

Umatilla, WA 97882-0700

J. Bishop

Rocky Mountain Elk Foundation

2291 W. Broadway

Missoula, MT 59802

L. Block

U.S. Fish and Wildlife Service

P.O. Box 1157

Moses Lake, WA 98837

K. Cadwell

Advance Science, Inc.

1777 Terminal Drive

Richland, WA 99352-4952

3 Confederated Tribes and Bands of the Yakama Indian Nation

P.O. Box 151

Toppenish, WA 98948

ATTN: B. Cook

J. Bauer

R. Tulee

3 Confederated Tribes of the Umatilla Indian Reservation

P.O. Box 638

Pendleton, OR 97801

ATTN: A. Childs

T. Gilmore

J. R. Wilkinson

L. Childers

U.S. Fish and Wildlife Service

2625 Parkmount Lane, S.W.

Building B

Olympia, WA 98502

\section{Distribution}

No. of

Copies

T. Clausing

Washington Department of Wildlife

Regional Habitat Program Manager 2802 Fruitvale Blvd.

Yakima, WA 98902

R. Duff

Washington Department of Wildlife 1550 Alder Street, N.W.

Ephrata, WA 98823-9651

D. Dunning

Oregon Department of Energy

625 Marion Street NE

Salem, OR 97310

J. Erickson

Thurston Airdustrial Center

Building 5, MS LE-13

Olympia, WA 98504

L. Fitzner

Washington Department of Wildlife

Route 2 Box 2128-Z

Benton City, WA 99320

D. Goeke

Columbia National Wildlife

Refuge Complex

P.O. Box F

Othello, WA 99349

2 Golder Associates, Inc.

4104 148th Avenue NE

Redmond, WA 98052

ATTN: L. Swenson

Library

J. Hunt

University of Idaho

Idaho Cooperative Fisheries Unit

Moscow, ID 83843

2 IT Corporation

1045 Jadwin Avenue, Suite C

Richland, WA 99352

ATTN: J. Chiramonte

D. A. Myers 
No. of

Copies

J. Johnson

National Audubon Society

209 N. Clinton

Walla Walla, WA 99362

D. Linehan

McNary National Wildlife Refuge

P.O. Box 308

Burbank, WA 99323

3 Nez Perce Tribe

P.O. Box 305

Lapwai, ID 83540

ATTN: D. Conrad

S. Harris

D. Powaukee

G. Norman

Washington Department of Fisheries

P.O. Box 999, S-13

Battleground, WA 98604

A. Palmer

U.S. Ecology

5333 Westheimer, Suite 100

Houston, TX 77056-5407

L. Popejoy

Washington Department of Wildlife

1701 S. 24th Avenue

Yakima, WA 98902-5720

D. Rondorf

U.S. Fish and Wildlife Service

National Fishery Research Center

Star Route

Cook, WA 98605

V. Schockley

Washington Public Power Supply System

Richland, WA 99352

P. Sleeger

U.S. Department of Interior

500 NE Multnomah, Suite 600

Portland, OR 97232

C. Soper

The Nature Conservancy

217 Pine Street, Suite 1100

Seattle, WA 98101
No. of

Copies

K. Sycamore

National Park Service

Pacific NW Region

$83 \mathrm{~S}$. King Street

Seattle, WA 98104

M. Toner

National Marine Fisheries Service

Pt. Adams Biological Field Station

Hammond, OR 97121

2 U.S. Bureau of Land Management

Spokane District Office

4217 E. Main Street

Spokane, WA 90202

ATTN: A. Aldridge

J. Jabosky

4 U.S. Fish and Wildlife Service Olympia Field Office 3704 Griffin Lane SE, Suite 102

Olympia, WA 98501-2192

ATTN: K. Benkert

J. Grettenberger

J. W. Haas

D. Kaumheimer

2 Washington Department of Ecology 7601 W. Clearwater, Suite 102

Kennewick, WA 99336

ATTN: J. Phillips

D. Teel

2 Washington Department of Ecology P.O. Box 47600

Olympia, WA 98504-7600

ATTN: D. Silver

S. Cross

3 Washington Department of Wildlife 100 Capital Way North, MS GJ-11

Olympia, WA 98501-1091

ATTN: J. Jacobson

R. Johnson

H. Allen

R. Willms

Washington Department of Fisheries 500 N. Morain, Box 14, Suite 1200B

Kennewick, WA 99336 
No. of

Coples

ONSITE

2 U.S.Army Coros of Engineers

A. Foote

W. D. Perro

A5-20

A5-19

6 U.S. Environmental Protection Agency
P. R. Beaver
D. R. Einan
D. A. Faulk
L. E. Gadbois
P. S. Innis
D. R. Sherwood

B5-01

B5-01

B5-01

B5-01

B5-01

B5-01

47 DOE Richland Operations Office

\section{J. D. Bauer}

K. W. Bracken

R. F. Brich

R. M. Carosino

K. V. Clarke

P. F. Dunigan, Jr.

B. L. Foley

E. D. Goller

E. A. Green

J. B. Hall

R. D. Hildebrand (20)

R. G. Holt

D. K. Jones

R. A. Holten

R. G. McLeod

P. M. Pak

C. R. Pasternak

M. J. Plahuta

R. O. Puthoff

T. R. Sheridan

R. K. Stewart

A. E. Teimouri

K. M. Thompson

D. L. Vieth

P. W. Willison

S. H. Wisness

Public Reading Room (2)

30 Westinghouse Hanford Company

M. R. Adams

R. A. Carlson

A5-90

A5-55

A5-19

A5-19

A7-27

A7-27

A5-10

R3-73

A5-19

A5-15

A5-15

R3-73

A4-52

A5-15

A1-65

H6-01

H6-03
No. of

Copies

S. W. Clark

H6-01

J. H. Dunkirk

B3-15

T. W. Ferns

H6-26

G. E. Fitzgibbon

H6-07

H6.02

$\mathrm{X} 0-21$

N3-06

H6-02

H6-03

H6-30

H6-04

H6-04

H6-02

H4-14

H6-01

H6-01

H6-22

H6.04

H6-04

H4-14

H6-04

H4-14

H6-30

H6-07

H6-02

H6-22

H6.26

H6-02

48 Pacific Northwest Laboratory
J. F. Bagley

C. A. Brandt

L. L. Cadwell (20)

C. E. Cushing

D. D. Dauble

J. L. Downs

S. L. Friant

D. R. Geist

R. H. Gray

J. A. Hall

I. D. Hays

R. E. Jaquish

T. E. Jones

T. K. Lucas

R. Mazaika

D. A. Neitzel

K. M. Probasco

W. H. Rickard

L. E. Rogers
$\mathrm{K} 1.66$

K6-60

K6-63

K6.54

K6-54

K6-63

K6-52

K6-54

B1-34

K6-63

K1-66

B1-34

K1-30

K6-52

K6-63

K6-54

K6-52

K6-63

K6-63 
No. of

Copies

Pacific Northwest Laboratory (contd)

G. M. Stokes

B. L. Tiller

R. K. Woodruff

Publishing Coordination

Technical Report Files (5)
No. of

Copies

\section{Routing}

K1.74

K6-63

K6-61

K1.06
R. M. Ecker

M. J. Graham

P. M. Irving

C. S. Sloane

P. C. Hays/G. P. O'Connor (last)
SEQUIM

K6.78

$\mathrm{K} 6-98$

K6-04

K6.86 

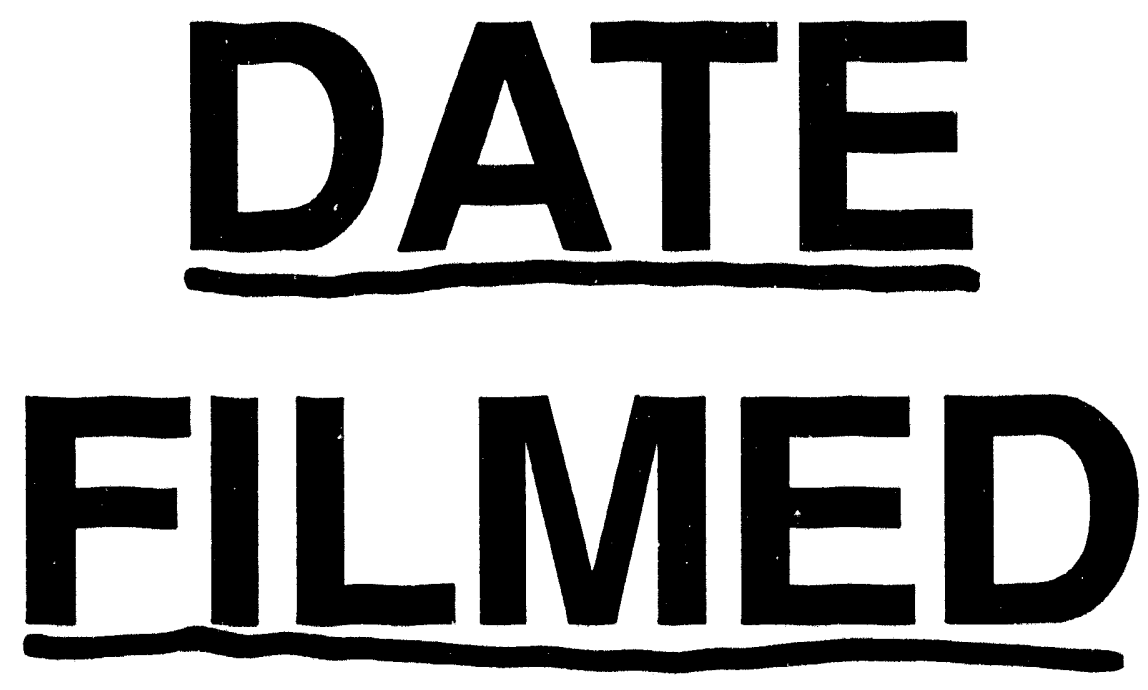

$6 / / 5 / 94$
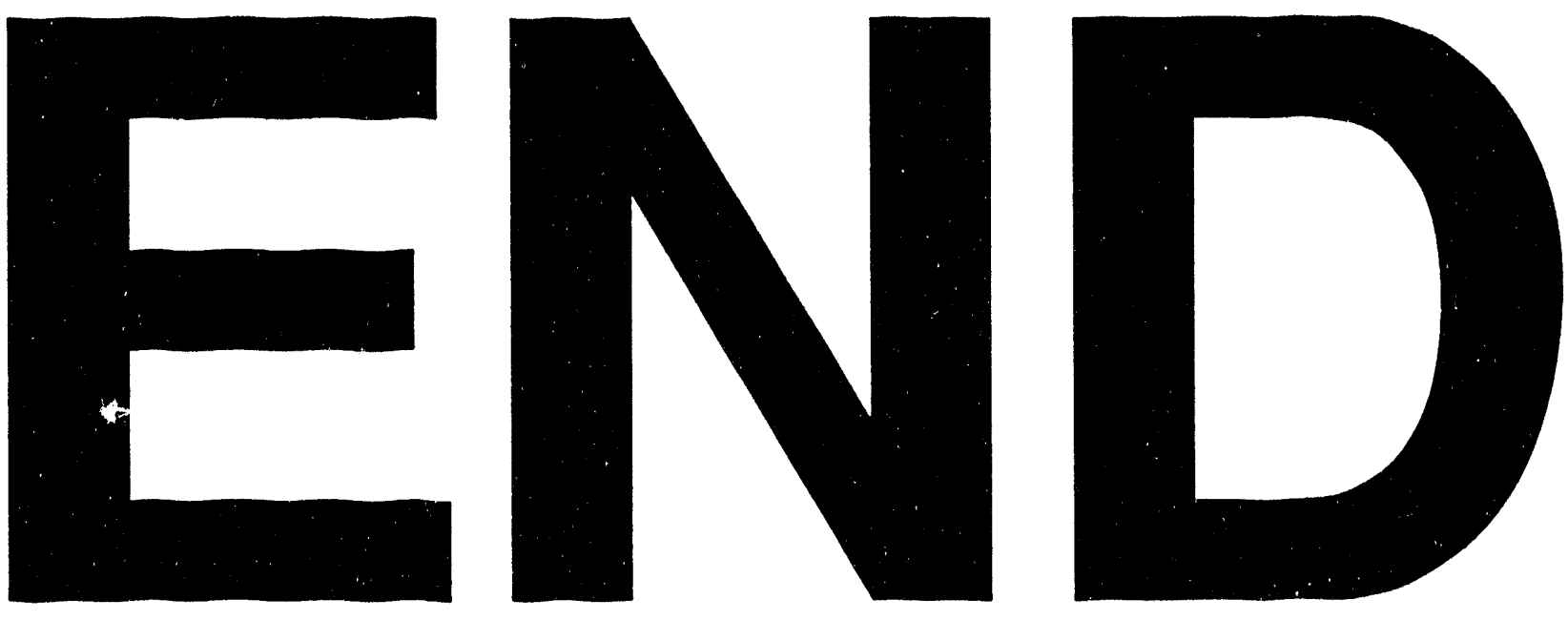